\title{
SOBRE O RECONHECIMENTO NA REPÚBLICA FEDERATIVA DO BRASIL DE DIPLOMA DE PÓS-GRADUAÇÃO STRICTO SENSU EM DIREITO CANÔNICO EXPEDIDO POR UNIVERSIDADE DA SANTA SÉ
}

\author{
Eduardo Antônio Klausner ${ }^{1}$
}

RESUMO: O presente trabalho investiga se é possível reconhecer no Brasil diploma de pósgraduação stricto sensu em Direito Canônico, expedido por instituição de ensino superior pertencente à Santa Sé, para que sejam produzidos efeitos equivalentes aos graus acadêmicos de Mestre ou Doutor em Direito conferidos no país. O Acordo Brasil - Santa Sé, em vigor desde 11 de fevereiro de 2010, assegura o reconhecimento recíproco de títulos e qualificações em nível de pós-graduação, observadas as exigências do ordenamento jurídico brasileiro e as da Santa Sé. A questão é nova e, apesar da sua evidente importância, ainda não foi enfrentada pelos meios acadêmicos em sua inteireza, havendo incerteza sobre a natureza do Direito Canônico, sobre os requisitos exigidos para a concessão do grau e a compatibilidade com o grau de Mestre ou Doutor em Direito conferidos no Brasil. À fim de alcançar o desiderato da pesquisa se adotará o método analítico com exame da doutrina, da legislação e da jurisprudência para que se possa determinar, em primeiro lugar, a natureza do Direito Canônico, se saber jurídico ou teológico; em segundo lugar, se a instituição de ensino superior mantida pela Santa Sé pode ser considerada instituição estrangeira de educação superior e pesquisa segundo a lei brasileira; e, em terceiro lugar, se o diploma em Direito Canônico que a instituição universitária romana concede é apto ao reconhecimento, mesmo que o curso de pós-graduação stricto sensu seja integralmente realizado no Brasil.

PALAVRAS-CHAVE: Revalidação de diploma estrangeiro; Reconhecimento de grau, título ou qualificação em Direito Canônico; Acordo Brasil - Santa Sé; Igreja Católica e Direito; Direito e Teologia; Direito Internacional Privado e Direito Canônico.

\section{Introdução}

O objetivo da presente pesquisa é verificar se diplomas e títulos de pós-graduação stricto sensu em Direito Canônico, expedidos por instituições de ensino superior da Santa Sé, podem ser reconhecidos no Brasil como equivalentes aos títulos de Mestre e Doutor.

\footnotetext{
${ }^{1}$ Professor Permanente de Direito Internacional e Direitos Humanos da Universidade Católica do Rio de Janeiro - UCP. Juiz de Direito do Poder Judiciário do Rio de Janeiro.

Bacharel, Mestre e Doutor em Direito Internacional e da Integração Econômica pela Universidade do Estado do Rio de Janeiro - UERJ; Pós-Doutorando na Linha de Pesquisa Direitos Humanos, Democracia e Ordem Internacional da Pós-Graduação em Direito da Pontifícia Universidade Católica do Rio de Janeiro - PUC Rio. Instituição: Universidade Católica de Petrópolis - UCP, Rio de Janeiro. Brasil. E-mail: eaklausner@tjrj.jus.br
} 
A questão é importante considerando que o Brasil e a Santa Sé possuem acordo no qual “o reconhecimento recíproco de títulos e qualificações em nível de Graduação e PósGraduação" é admitido, desde que atendidos os requisitos legais brasileiros e da Santa Sé.

No Brasil o reconhecimento de diplomas estrangeiros de pós-graduação stricto sensu está previsto na Lei de Diretrizes e Base da Educação Nacional, Lei nº 9.394 de 1996, artigo $48^{\circ}, \S 3^{\circ}$. Assim, os títulos de Mestre e Doutor concedidos por instituições de ensino estrangeiras devem ser formalmente reconhecidos no Brasil para terem validade e produzirem os efeitos de direito inerentes ao título universitário.

A Resolução $\mathrm{n}^{\circ}$. 3, promulgada pela Câmara de Educação Superior do Conselho Nacional de Educação do Ministério da Educação brasileiro em 22 de junho de 2016 e publicada no Diário Oficial da União (DOU) em 23 de junho de 2016, disciplina a matéria e o procedimento a fim de que seja obtido o reconhecimento do diploma estrangeiro. A Portaria Normativa n. 22, do Ministro de Estado da Educação, promulgada em 13 de dezembro de 2016, regulamenta minunciosamente os atos procedimentais e institui a Plataforma Carolina Bori ${ }^{3}$, de adesão voluntária pelas instituições reconhecedoras, para subsidiar a execução e a gestão dos processos de reconhecimento de diplomas ${ }^{4}$.

Para cumprir o objetivo da pesquisa, impõe-se, em primeiro lugar, decidir qual instituição é competente para proceder o reconhecimento do diploma de pós-graduação stricto sensu em Direito Canônico, expedido por universidade da Santa Sé. Isso também implica em definir a natureza do Direito Canônico como saber científico.

Em segundo lugar, deve ser avaliada a organização acadêmica da instituição estrangeira, o seu desempenho na atividade de pesquisa e o seu procedimento para atribuição do grau acadêmico, conforme disposto no artigo 18 da Resolução acima citada. O objetivo da norma é constatar se existe equivalência entre o grau acadêmico estrangeiro e o pretendido pelo beneficiário do reconhecimento; bem como verificar se o curso de pós-graduação stricto sensu da instituição de ensino estrangeira possui exigências científicas rigorosas para a atribuição dos títulos de Mestre e Doutor, compatíveis com as determinações e as exigências legais brasileiras formuladas para a pós-graduação stricto sensu e para atribuição dos títulos de Mestre e Doutor, de modo a permitir um reconhecimento paritário ao nacional quanto à formação do seu titular, como previsto pela Lei 9.394/1996, artigo 48, caput.

\footnotetext{
${ }^{2}$ Artigo $9^{\circ}$. do Acordo entre a República Federativa do Brasil e a Santa Sé relativo ao Estatuto Jurídico da Igreja Católica no Brasil, promulgado pelo Decreto n. 7.107 de 11 de fevereiro de 2010.

${ }^{3} \mathrm{http}: / /$ carolinabori.mec.gov.br/?pagina=inicial.

${ }^{4}$ Artigo 5\%.
} 


\section{Instituição competente para o reconhecimento do diploma de pós-graduação stricto sensu em Direito Canônico}

A Resolução $n^{\circ} .3$ de 2016 já citada dispõe, em seu artigo 17, cuja redação é similar ao $\S 3^{\circ}$ do artigo 48 da Lei n. 9.394 de 1996, que:

os diplomas de cursos de pós-graduação stricto sensu (mestrado e doutorado), expedidos por universidades estrangeiras, só poderão ser reconhecidos por universidades brasileiras regularmente credenciadas que possuam cursos de pós-graduação avaliados, autorizados e reconhecidos, no âmbito do Sistema Nacional de Pós-Graduação (SNPG), na mesma área de conhecimento, em nível equivalente ou superior.

A norma acima citada é clara em seus termos e dispensa maiores esclarecimentos. Todas as universidades brasileiras, assim como os cursos de graduação e pós-graduação que oferecem, estão sujeitas ao permanente controle e fiscalização do poder público.

Ao exercer o múnus público de reconhecer como válido, para todos os efeitos de direito, um diploma estrangeiro, a universidade brasileira age como delegada da União, delegada essa com expertise na área de conhecimento do título estrangeiro que for avaliar. Nessa qualidade, afirma que os requisitos cumpridos no estrangeiro pelo diplomado são equivalentes aos que se exige no Brasil na área de conhecimento do título examinado, atribuindo equivalência entre o título estrangeiro e grau acadêmico que concede aos seus pós-graduandos aprovados ao final do curso para que possa valer no Brasil.

A acima mencionada exigência da Resolução decorre do fato de que, para o reconhecimento de diplomas estrangeiros, é preciso expertise na área de saber do diplomado por parte da comissão de docentes que irá participar do processo de reconhecimento. Essa expertise é fundamental para propiciar a comissão a competência científica necessária para avaliar o currículo, às exigências da instituição estrangeira quanto a dedicação aos altos estudos e à pesquisa por parte do corpo docente e discente, assim como às condições materiais fornecidas para tanto.

Professores e pesquisadores universitários brasileiros que se dedicam à pesquisas na mesma área de conhecimento do curso de pós-graduação estrangeiro, os quais laboram em cursos de nível equivalente ou superior com relação ao grau acadêmico obtido pelo diplomado no curso estrangeiro, estão habilitados para examinar os méritos e deméritos de um curso acadêmico alienígena tendo por paradigma o próprio curso de pós-graduação do qual participam.

Por sua vez, considerando a redação do citado artigo da Resolução, que não distingue universidades públicas ou privadas - diferente do tratamento dado a diplomas de graduação cuja revalidação só será feita por universidades públicas nos termos do artigo $3^{\circ}$ - conclui-se que instituições de ensino superior privadas são competentes para o ato de reconhecimento de diploma de pós-graduação stricto sensu estrangeiro. 
A problemática a ser enfrentada em razão do artigo regulamentar em comento diz respeito à determinação da área de conhecimento em que se situa o Direito Canônico: se é ramo da Ciência do Direito ou se é ramo da Teologia, como será em seguida demonstrado.

A questão é nova e ainda não foi enfrentada pelos meios acadêmicos seculares em sua inteireza, apesar da sua evidente importância. Determinar a área de conhecimento é condição sine qua non para definir a competência da universidade brasileira que procederá o reconhecimento do diploma de Direito Canônico estrangeiro, e para definir os direitos do titular do grau acadêmico no que diz respeito à sua habilitação em uma área do conhecimento.

Isso, consequentemente, indiretamente também repercutirá nos direitos da instituição de ensino que mantém o programa de pós-graduação do qual participará o diplomado em Direito Canônico, caso venha a ser contratado para a docência e a pesquisa, considerando o rigor das regras da Coordenação de Aperfeiçoamento de Pessoal de Nível Superior (CAPES) quanto ao número e à qualificação dos docentes na área de conhecimento do programa de pós-graduação stricto sensu mantido por universidade brasileira. Assim, impõe-se estabelecer com exatidão se o Direito Canônico está na área de conhecimento do Direito, ou se pertence à outra área de conhecimento.

\subsection{A determinação da área de conhecimento do Direito Canônico}

Direito, como termo, comporta diversos sentidos. Como área do conhecimento e do saber científico, Direito é a ciência que se dedica ao conhecimento do fenômeno jurídico. O fenômeno jurídico é entendido como a composição de fatos e atos referentes ao conjunto de normas reguladoras de conduta que organizam as relações do Estado e dos membros da sociedade civil, prescrevendo qual deve ser o comportamento socialmente aceito e qual deve ser a punição ou a consequência na hipótese de descumprimento dos preceitos normativos que são estabelecidos pela sociedade e pelo Estado, concretizados no tempo e no espaço (SOARES, 2015, p. 13-17 e REALE, 2007, p. 16-17).

A existência de variados conceitos e definições sobre o Direito tem por características, principalmente, o peso que se atribui a três elementos: o da legalidade conforme o ordenamento, o da eficácia social e o da correção material. Como esclarece Alexy (2009, p. 15):

quem não atribui importância alguma à legalidade conforme o ordenamento e à eficácia social e considera exclusivamente a correção material obtém um conceito de direito puramente jusnatural ou jusracional. Quem segrega por completo a correção material, focalizando unicamente a legalidade conforme o ordenamento e/ou a eficácia social chega a um conceito de direito puramente positivista. No espaço compreendido entre esses dois extremos é possível conceber muitas formas intermediárias. 
Bobbio (2008, p.3), por sua vez, explica que "nossa vida desenvolve-se em um mundo de normas"; ubi societas ibi ius, já diziam os juristas romanos. Esse mundo normativo posto pela sociedade e pelo Estado, que estipula ao ser humano uma conduta ideal na sociedade e na relação com terceiros, um dever-ser coercitivo e com sanção pré-determinada pelo descumprimento da conduta imposta, é a característica mor do Direito. Isso, independentemente das diversas correntes que discutem sobre a natureza, a formação, a validade, a legitimidade e a adequação do Direito à Justiça. O Direito possui, portanto, como principais atributos: a heteronomia, a coercibilidade e a bilateralidade atributiva ${ }^{5}$.

A Ciência Jurídica, ou Ciência do Direito, portanto, é aquela que tem por objeto o estudo do Direito e do fenômeno jurídico "tal como ele se concretiza no espaço e no tempo" (REALE, 2007, p. 16-17). Como toda ciência, "é discurso, teoria, que se constrói em função de um objeto de conhecimento e de um método, por sua vez também construídos" com função precípua de explicar, "e não ditar normas e, muito menos, dogmatizar" (MARQUES NETO, 2001, p. 184$185)$.

Como ciência social, ou política ${ }^{6}$, visa a uma aplicação. A especificidade técnica ou tecnológica do Direito se materializa na norma válida em um sistema normativo de observância coercitiva pelo corpo social, e na aplicação técnico-normativa (MARQUES NETO, 2001,p. 185) pelos juristas ${ }^{7}$. A norma, nesse sentido, por sua vez, engloba o preceito que pode ser genericamente nomeada como lei assim como os princípios, ambos com características próprias e sujeitos à aplicação por métodos e técnicas específicas nas relações jurídicas travadas na sociedade.

O Direito, para organizar a vida em sociedade, necessita categorizar fenômenos jurídicos, formar conceitos e definições jurídicas, e estipular instituições jurídicas. Assim, o Direito, por natureza, constrói instituições jurídicas e qualifica fenômenos jurídicos de maneira sistemática e organizada, a fim de evitar uma mera justaposição de regras que comportaria incoerências e contradições. "Portanto, o direito constitui inevitavelmente um sistema

\footnotetext{
${ }^{5}$ Como destacam, entre outros, REALE (Lições Preliminares de Direito,2007, p. 44-52; Filosofia do Direito, 2002, p. 699-710); e BITTAR e ALMEIDA (2010, p. 519-520). No mesmo sentido, BERGEL (2006, p. 3943). Tais características são do sistema normativo como um todo, como esclarece BOBBIO (2008, p. 147), o que justifica a existência de normas jurídicas sem sanção no sistema.

6 Alguns autores entendem que o Direito deve ser libertado do caráter científico-positivo que contemporaneamente tem sido preferido, pois adequa-se melhor a Política, assim entendida como Filosofia Política ou Ciência Política. Nesse sentido, citando diversos juristas nacionais e estrangeiros com o mesmo posicionamento, Jacques (1981, p. 6-11).

${ }^{7}$ Juristas são os peritos ou especialistas em Direito. Os juristas por excelência são os Juízes. Também são juristas os Promotores de Justiça, os Advogados, além dos Notários, Registradores e "qualquer ofício ou profissão em que seja necessário estabelecer o direito em relação a algumas pessoas ou instituições." (HERVADA, 2008, p. 54-60).
} 
organizado em torno de certo número de princípios, de noções fundamentais, de procedimentos técnicos cujo emprego pressupõe certos métodos", e as regras jurídicas são oriundas da "associação de maior ou menor número de conceitos e todo sistema de direito se caracteriza por uma organização específica das relações existentes entre seus diversos elementos" (GASSIN, 1981, p. 353 apud BERGEL, 2006, p. 252).

Por sua vez, em razão da complexidade das relações jurídicas, torna-se necessária a divisão do Direito em ramos especializados, com determinação de objeto próprio e princípios peculiares. A certeza e a segurança na apreensão dos fenômenos jurídicos e na utilização de critérios uniformes para a identificação da facti species normativa, bem como para determinar as hipóteses de incidência da norma, exige um quadro teórico definido e especializado (FERRAZ Jr, 2008, p. 109-116).

O Direito possui princípios e normas gerais, mas, conforme a natureza de cada grupo de relações jurídicas ou fatos jurídicos, também possui princípios diretores, regras e instituições peculiares a determinados fenômenos e categorias jurídicas assemelhadas por um elemento ou característica comum, os quais formam um corpo normativo especial, organizado e sistematizado em regime próprio, adequado aos fenômenos sociais, econômicos e jurídicos aos quais se destinam. Essa especialização não significa uma separação absoluta, deve ser frisado, mas principalmente a determinação de critérios de decidibilidade com certeza e segurança (FERRAZ Jr., 2008, p. 112-116).

Entre os juristas seculares, há poucas divergências sobre a natureza do Direito Canônico. Tenório (1976, p. 413) abraça a definição de Bertola (p. 920): “o complexo das leis estabelecidas ou aprovadas pela Igreja para o governo da sociedade eclesiástica e para a disciplina das relações dos fiéis. Em sentido restrito é o Codex iuris canonici”. Tenório (1976, p. 413) ainda afirma que:

\footnotetext{
No campo de aplicação do direito canônico, não há controvérsia quando a lei do Estado admite sua incorporação. Integra-se, então, no ordenamento jurídico do país, nos rigorosos limites admitidos. Fora do texto da lei, o problema é de qualificação do direito canônico, qualificação que oscila entre a de sua natureza de direito estrangeiro e a de sua expressão estatutária, desde que não seja incompatível com a ordem pública local.
}

Afirma ainda o acima citado jurista que, sendo o Direito Canônico direito da Igreja Católica "para as relações de seus fiéis, independentemente de nacionalidade ou do domicílio", não pode ser considerado propriamente direito estrangeiro, mas reconhece existir certas "manifestações contraditórias e vacilantes" na jurisprudência (TENÓRIO, 1976, p. 414). No entanto, apesar de divergências quanto à qualificação do Direito Canônico, seja como corpo de normas estatutárias de organizações religiosas, seja como o direito decorrente de um "corpo de 
leis que emana das autoridades legislativas da Igreja e é imposto obrigatoriamente aos seus fiéis", não há dúvidas de sua característica normativa e coercitiva (TENÓRIO, 1976, p. 421).

Por sua vez, alguns dicionários jurídicos seculares contêm verbetes definindo Direito Canônico, não o distinguindo dos demais ramos da Ciência do Direito. Cite-se, por exemplo, De Plácido e Silva (1995, p. 79):

"DIREITO CANÔNICO. Assim se designa o corpo ou coleção de leis que regem a Igreja Católica. [...].

Entre os canonistas a questão não é tão simples. Três principais correntes divergem sobre a natureza do Direito Canônico: a teológica, a pastoral e a jurídica (STEFFEN, 2014).

Hervada (2006, p. 169-173), jurista secular e canonista, é categórico sobre a natureza do Direito Canônico como ramo da Ciência do Direito, in verbis:

Nas origens da ciência jurídica moderna encontramos não só os legistas, [...] como também os canonistas, com a figura também não muito conhecida do mestre Graciano. [...] a ciência jurídica moderna, em suas origens, deve tanto aos legistas quanto aos canonistas o que, unido ao regime jurídico dos Estados e suas relações com a Igreja Católica (regime de Cristandade), originou o sistema do utrumque ius, dos dois direitos: o ius civile (direito civil) e o ius canonicum (direito canônico), que durante séculos regeu a vida jurídica da Europa.

Com o advento da Reforma protestante, esse sistema desapareceu para que o direito canônico ficasse dentro dos limites da Igreja Católica. Porém, embora separado do direito secular, o direito canônico continuou vivo e os canonistas constituíram um setor importante da ciência jurídica, com suas Faculdades de Direito Canônico e uma atividade científica e prática intensa. Não se deve esquecer, entretanto, que o direito canônico rege matérias muito relevantes para a vida dos homens, como o casamento, em uma comunidade independente e soberana que conta com milhões de fiéis, que superam em número, com grande diferença, os Estados mais habitados e extensos. Nenhum direito dos Estados mais habitados - ainda contando com o direito das uniões de Estados como a União Europeia - tem vigência em extensão que o direito canônico tem. [...]

Essas inegáveis diferenças de conteúdo entre o direito canônico e o direito secular não devem induzir ao engano sobre a genuína natureza do direito canônico. Na Igreja, existem verdadeiras relações de justiça comutativa (v.g. contratos), justiça distributiva (v.g., os fiéis têm direito aos sacramentos) e justiça legal (há na Igreja autêntica potestade legislativa e de regime ou executiva e judicial); e a Instituição conta com um direito penal e com um sistema judicial etc.

Se existe verdadeira justiça, existe verdadeiro ius, [...]

Por isso, [...] ser canonista é ser jurista, a ciência canônica é um importante ao mesmo tempo original - setor da ciência jurídica, e o método a seguir é um método jurídico".

O canonista Gigante (1955, p.5) define Direito Canônico como ramo dogmático do Direito, frisando o seu aspecto eminentemente normativo e jurídico: "Direito Canônico é o sistema ou complexo de leis com que a Igreja regula a sua atividade social específica e a de seus membros como tais". 
Alguns canonistas, antes mesmo de conceituar e abordar a natureza do Direito Canônico, frisam que o Direito Canônico não é Teologia, ou ramo da Teologia v. g., Gonçalves (2004, p. 32-34, 53-54) com base no ensinamento de Sóbánski (1977, p. 74):

\begin{abstract}
Se perguntarmos o que é Direito Canônico, podemos também completar nossa interrogação fazendo uma outra pergunta suplementar: o que não é Direito Canônico?

Em primeiro lugar, o Direito Canônico não é Teologia prática, isto é, um estudo sistemático sobre as práticas eclesiais [...] o Direito Canônico não é um discurso da fé ou Teologia, nem tem preocupação de celebrá-la, como é próprio da liturgia.

[...] a vida e a missão da Igreja, para poder desenvolver-se, exigem ordenamento, regras, leis de conduta, ou seja, uma ordem disciplinar.

[...] Entende-se por Ciência Canônica a exposição científica do complexo de leis da Igreja Católica, de acordo com certos princípios e organizados numa ordem lógica. Daí que "quando um jurista se ocupa do Direito Canônico como um fenômeno jurídico, se serve dos métodos em uso nas ciências jurídicas, que levam-no ao conhecimento do Direito, portanto, do método analítico, do método sistemático e do histórico. Como outros Direitos, também o Canônico, indagado pelo jurista, mostra a sua própria especificidade, enquanto é observado como direito de uma comunidade religiosa".
\end{abstract}

O Direito Canônico é uma necessidade da Igreja Católica Apostólica Romana, uma vez que a Igreja se organiza na sociedade humana como uma instituição, atribuindo direitos e deveres aos seus membros por preceitos de observância coercitiva. O Direito Canônico tem por fontes, quanto ao legislador e aos principais documentos, Deus e sua legislação divina proveniente da Revelação Cristã materializada no Antigo e no Novo Testamento, bem como as autoridades humanas que governam a Igreja e editam leis, decretos e sentenças para tanto ${ }^{8}$.

O Direito Natural com matriz teológica, tendo por fundamento ou fonte Deus, a legislação divina e o ordenamento religioso, não é estranho à Ciência do Direito. Essa é a doutrina que predominou no estudo e na justificação do Direito antes mesmo de Cristo, como no direito hebraico, no direito grego e no direito romano, por exemplo, e que, fundado na Revelação Cristã, predominou no Ocidente até o século XVI com o advento da Reforma e do jusnaturalismo racionalista.

Destaque-se que o Direito Natural, tendo por fonte Deus, a lei divina e o ordenamento religioso decorrente da sua soberana divindade, predomina em outras tradições, organiza a sociedade civil, é formalmente recepcionado nas Constituições dos Estados e inspira a legislação secular de diversos países muçulmanos, como, por exemplo, ocorre na Arábia Saudita, no

\footnotetext{
${ }^{8}$ Nesse sentido: Andreau-Guitrancourt (1963, p. 281-288, 410 e s).; Le Tourneau (1998, p. 17-25); e Gigante $(1955$, p. 7 e s.).
} 
Paquistão e no Irã. Nesses Estados a validade do Direito reside no Direito Islâmico e suas fontes: o Alcorão, a Sunnah e a Charia, (ou Shari'ah) ${ }^{9}$.

Sobre a origem de um Direito Canônico sistematicamente e juridicamente organizado no seio da Igreja Católica, explica Lima (1999, p.19):

O fenômeno jurídico-eclesiástico que se verifica nos vinte séculos de existência da Igreja Católica decorre, portanto, de sua própria natureza, cujas leis provêm de sua constituição, que, embora divina em sua origem, é humana nas pessoas que a compõem e, inserida na grande sociedade humana, por isso mesmo, sem perder de vista o sobrenatural, necessariamente passível de evolução. Se suas leis se destinam a governar a vida prática dos que se associam a ela [...].

A autoridade eclesiástica, por sua vez, enfatiza o caráter jurídico da legislação canônica.

Cite-se, a título de exemplo, a mais importante legislação da Igreja Latina: o Código de Direito Canônico. Sua Santidade o Papa João Paulo II, ao promulgar o novo Código de Direito Canônico, é claro ao enfatizar o caráter jurídico do mesmo:

$[\ldots]$

Surge agora uma outra questão sobre a natureza do próprio Código de Direito Canónico. Para responder devidamente a esta pergunta, é preciso recordar o antigo património de direito contido nos livros do Antigo e do Novo Testamento, de onde provém, como da sua primeira fonte, toda a tradição jurídica e legislativa da Igreja.

$[\ldots]$

O Código, como principal documento legislativo da Igreja, baseado na herança jurídica e legislativa da Revelação e da Tradição, deve considerar-se o instrumento indispensável para assegurar a ordem tanto na vida individual e social, como na própria atividade da Igreja. Por isso, além de conter os elementos fundamentais da estrutura hierárquica e orgânica da Igreja, estabelecidos pelo seu Divino Fundador ou baseados na tradição apostólica ou na mais antiga tradição, e ainda as principais normas referentes ao exercício do tríplice múnus confiado à própria Igreja, deve o Código definir também as regras e as normas de comportamento.

Um instrumento, como é o Código, corresponde totalmente à natureza da Igreja, sobretudo como é proposta pelo magistério do Concílio Vaticano II, [...]

De facto, o Código de Direito Canónico é absolutamente necessário à Igreja. Já que ela também está constituída como um todo orgânico social e visível, tem necessidade de normas, para que a sua estrutura hierárquica e orgânica se torne visível, para que o exercício das funções a ela divinamente confiadas, especialmente a do poder sagrado e a da administração dos Sacramentos, possa ser devidamente organizado, para que as relações mútuas dos fiéis possam ser reguladas segundo a justiça baseada na caridade, garantidos e bem definidos os direitos de cada um, e, enfim, para que as iniciativas comuns, assumidas para uma vida cristã cada vez mais perfeita, sejam apoiadas, fortalecidas e promovidas mediante as normas canónicas.

\footnotetext{
${ }^{9}$ Sobre o tema Direito na antiguidade, especialmente grego e romano ver, Coulanges (2003 edição brasileira, sem as notas de rodapé da edição original, pela RT). Sobre o Direito Hebraico ver: Palma (2007, Juruá). Sobre o Direito Islâmico ver: Morêz (2008, Juruá). Sobre sistemas jurídicos contemporâneos com fonte no Direito Divino, ver: David (2002, Martins Fontes) e Losano (2007, Martins Fontes). Para um rápido panorama sobre o sistema jurídico israelense, indiano, árabe saudita e paquistanês, ver: Klausner (2012,p. 142-155).
} 
Finalmente, as leis canónicas pela sua própria natureza devem ser observadas; por isso foi usada a máxima diligência, para que na longa preparação do Código a expressão das normas fosse precisa e elas se apoiassem num sólido fundamento jurídico, canónico e teológico.

Depois de todas estas considerações, deve sem dúvida augurar-se que a nova legislação canónica se torne um instrumento eficaz com que a Igreja possa aperfeiçoar-se de acordo com o espírito do Concílio Vaticano II, e mostrar-se cada vez mais capaz de cumprir neste mundo a sua missão salvífica. $[. . .]^{10}$

A Reunião Geral do Sínodo dos Bispos de 1967, que definiu os princípios que regeriam os trabalhos para a revisão do Código de Direito Canônico, foi cristalina ao se expressar sobre a índole jurídica do Código citado, v.g., no primeiro, no sétimo e no nono princípios, in verbis:

$1^{\circ}$.) Na renovação do direito, deve-se absolutamente conservar a índole jurídica do novo Código, exigida pela própria natureza social da Igreja. [...] $7^{\circ}$.) [...] é necessário que se consagre atenção especial à regulamentação do procedimento destinado à garantia dos direitos subjetivos. Por isso, na renovação do direito, atenda-se ao que tanto faltava nesse particular, até o presente, isto é, aos recursos administrativos e à administração da justiça. Para obter isso, faz-se necessário distinguir claramente as diversas funções do poder eclesiástico, a saber, as funções legislativas, administrativa e judicial, e determinar adequadamente que organismos devam exercer cada função.

[...]

$9^{\circ}$.) Com referência ao direito de coação, a que a Igreja não pode renunciar, como sociedade externa, visível e independente, as penas sejam geralmente ferendae sententiae e irrogadas e remitidas somente no foro externo. $[. . .]^{11}$

Na perspectiva científica secular, ou seja, da Ciência do Direito, ou mesmo de Direito Civil, que é como os canonistas nomeiam o Direito que tem por fonte somente normas do Estado, os estatutos e as normas particulares de organizações religiosas, associações, sociedades civis ou comerciais e corporações em geral que têm personalidade jurídica segundo o Direito Privado obrigam os partícipes e membros das mesmas. Essa coercitividade dos estatutos e normas particulares decorre do próprio reconhecimento estatal das mesmas como fontes subsidiárias de normatividade, como consequência da autonomia negocial das pessoas envolvidas nesses negócios jurídicos. Na linguagem de Kelsen todas essas “corporações” são uma ordem jurídica personificada. Nesse sentido, a Igreja Católica é uma corporação.

As corporações são tradicionalmente definidas e concebidas como (GRAY, p. 51, apud KELSEN, 2005, p. 157), “um corpo organizado de homens ao qual o Estado deu poderes para

${ }^{10}$ SANTA SÉ. João Paulo II, PAPA. Constituição Apostólica "Sacrae Disciplinae Leges" de Promulgação do Código de Direito Canônico. 1983. Roma, Palácio Vaticano.

${ }^{11}$ SANTA SÉ. Comissão para a Revisão do Código de Direito Canônico. Prefácio. Código de Direito Canônico. 1983, Vaticano. 
proteger os seus interesses, e as vontades que acionam esses poderes são as vontades de certos homens determinados segundo a organização."

A definição acima é criticada por Kelsen, que nela vê uma "hipostatização". Numa perspectiva do positivismo jurídico normativo, a própria organização como pessoa jurídica confunde-se com a sua própria ordem normativa, nada mais é do que uma ordem personificada. Nesse sentido, no caso em exame, a Igreja Católica confunde-se com o seu próprio Direito Canônico. Kelsen (2005, p. 144) é peremptório nesse sentido:

f. A pessoa jurídica como ordem personificada A pessoa jurídica, no sentido mais restrito do termo, nada mais é que a personificação de uma ordem que regula a conduta de vários indivíduos; por assim dizer, o ponto comum de imputação para todos os atos humanos, que são determinados pela ordem.

Isso porque, para o positivismo jurídico normativo, a pessoa jurídica, que é como se constitui a Igreja Católica, - e outras organizações religiosas -, à luz da Ciência do Direito, assim como todas as demais entidades a ela pertencentes ou associadas, é formada por um grupo de indivíduos tratados pelo Direito como uma unidade. Assim explica Kelsen (2005, p. 140) ipsis litteris:

[...] ou seja, como uma pessoa que tem direitos e deveres distintos daqueles dos indivíduos que a compõem. Uma corporação é considerada como uma pessoa porque nela a ordem jurídica estipula certos direitos e deveres jurídicos que dizem respeito aos interesses dos membros da corporação, mas que não parecem ser direitos e deveres dos membros e são, portanto, interpretados como direitos e deveres da própria corporação. Tais direitos e deveres são, em particular, criados por atos dos órgãos da corporação.

O sistema normativo oriundo da Igreja Católica, como o sistema normativo que organiza todo o tipo de corporação ou pessoa jurídica, portanto, é reconhecido pelo próprio Estado como Direito. Esse sistema normativo de fonte corporativa é essencial para a existência da própria pessoa jurídica e, no caso, da própria Igreja como ente dotado de personalidade jurídica na sociedade e perante o Estado, e é ordem normativa jurídica no sentido estrito do termo. Como leciona Kelsen (2005, p. 142-143):

Dizer que esta associação possui órgãos é exatamente o mesmo que dizer que os indivíduos que formam a associação estão organizados por uma ordem normativa. A ordem ou organização que constitui a corporação é o seu estatuto, os chamados regulamentos da corporação, um complexo de normas que regulamenta a conduta dos seus membros. Deve-se notar aqui que a corporação existe juridicamente apenas através do seu estatuto. [...] Os indivíduos "pertencem" a uma associação ou formam uma associação apenas na medida em que a sua conduta é regulada pela ordem "da" associação. $\mathrm{Na}$ medida em que a sua conduta não é regulada pela ordem, os indivíduos não 
“pertencem” à associação. Os indivíduos são associados apenas através da ordem. [...] Portanto, é enganoso dizer que uma associação ou comunidade é "formada" ou composta de indivíduos, como se a comunidade ou associação fosse apenas um amontoado de indivíduos. A associação ou comunidade é composta apenas pelos atos dos indivíduos que são determinados pela ordem; e esses atos "pertencem" à associação ou comunidade apenas na medida em que formam o conteúdo das normas da ordem. A associação ou comunidade nada mais é que a "sua" ordem.

Portanto, superada está toda e qualquer pretensão de não se considerar o Direito Canônico como ramo da Ciência do Direito, por uma alegada e inverídica ausência de coercibilidade $^{12}$ só encontrada no direito positivo estatal, ou por se considerar equivocadamente a Ciência Canônica como ramo da Teologia ${ }^{13}$.

A relação entre Direito Canônico e a Teologia decorre da fundamentação da Ciência Canônica na lei divina e de justificar-se o Direito como um dos meios para que a Igreja atinja o seu desiderato: pregar os Evangelhos, proporcionar o necessário para contribuir com a construção do Reino de Deus e a Salvação dos homens. No entanto, o Direito Canônico participa da natureza geral do Direito ${ }^{14}$. Ressalte-se que o Direito possui intrínseca a interdisciplinaridade, sem que isso afete a sua natureza jurídica, pelo contrário, enriquecendo-o na construção do seu saber $^{15}$.

No Brasil, o Código Civil materializa no direito positivo o que teoricamente explica Kelsen, ao dispor no artigo 44, IV, e $\S 1^{\circ}$., serem as organizações religiosas pessoas jurídicas de direito privado ${ }^{16}$, de livre criação, organização, estruturação interna e funcionamento, sendo vedado ao poder público negar-lhes reconhecimento ou registro dos atos constitutivos e necessários ao seu funcionamento. Por sua vez, os artigos 45 a 52 do Código Civil dão o suporte legal necessário para o desenvolvimento das atividades das organizações religiosas ${ }^{17}$.

O Código Civil brasileiro ao estipular quem são as pessoas jurídicas, preocupa-se também com a natureza jurídica das mesmas de maneira ampla, classificando-as como de direito público interno e externo e de direito privado em seu artigo 40 para, nos artigos seguintes, definir

\footnotetext{
${ }^{12}$ Nesse sentido, Sampel (2002, p. 104-105, versão eletrônica:< http://revistas.pucsp.br/culturateo>).

${ }^{13}$ Zani (2007, p. 140, versão eletrônica idem) afirma que o Direito Canônico é ramo da Teologia, confundindo o interesse interdisciplinar com aspectos dogmáticos e epistemológicos.

${ }^{14}$ Nesse sentido, Mörsdorf (Direito Canônico. FRIES, Heinrich (diretor). Dicionário de Teologia: conceitos fundamentais da teologia atual. 1970, p. 412).

${ }^{15}$ Como bem destaca a CAPES, Diretoria de Avaliação. LIMA, Martonio Mont'Alverne Barreto, Coordenador de Área. Documento de Área 2013 - Área de Avaliação: Direito, p. 4-5

${ }^{16}$ Sobre o tema no Brasil, ver também: Aguillar (2015, LTr).

${ }^{17}$ Cf. Baldisseri (2011, p. 56-57 e nota de rodapé n. 1), o Decreto n. 119-A de 07 de janeiro de 1890 já assegurava a liberdade religiosa no Brasil e reconhecia a todas as igrejas e confissões religiosas personalidade jurídica.
} 
cada uma delas. Nesse diapasão, viu-se mais acima que as organizações religiosas são pessoas jurídicas de direito privado na forma do artigo 44, IV, do citado Codex.

No entanto, a Igreja Católica, entre todas as organizações religiosas, tem um caráter e uma natureza anômala, pois a Santa Sé, que governa a Igreja Católica Apostólica Romana e o Estado da Cidade do Vaticano, também é pessoa jurídica de direito público externo, conforme define o artigo 42 do Código Civil, por se enquadrar como ente regido pelo Direito Internacional Público.

Como os demais Estados a Santa Sé tem sua soberania reconhecida mundialmente na sociedade de Estados e na Organização das Nações Unidas (BALDISSERI, 2011, p. 23-30, 85 e s.), da qual participa na qualidade de observador. O Papa governa a Santa Sé como um monarca absoluto sediado no Estado da Cidade do Vaticano, - um enclave em Roma, capital da Itália -, e a sua soberania é garantida pelo Estado italiano formalmente pelo Tratado de Latrão de $1929^{18}$. A Santa Sé, como os demais entes soberanos, promulga seu próprio direito, o Direito Canônico, com o qual se organiza e ordena as relações sob sua jurisdição estatal, eclesial e religiosa, bem como celebra tratados, tratados esses que também criam e regulam direitos, (tradicionalmente conhecido como Direito Concordatário), e participa de organismos internacionais ${ }^{19}$. Mazzuoli (2012, p. 440) frisa que o reconhecimento da personalidade internacional da Santa Sé é histórico e nunca foi contestado à luz do direito das gentes. Em razão desta soberania, a Santa Sé mantém relações diplomáticas com 178 países, com organizações internacionais e participa de diversos organismos intergovernamentais. Atualmente há mais de 180 representantes estrangeiros credenciados junto a Santa Sé (BALDISSERI, 2011, p. 50-51).

A Santa Sé também mantém relações internacionais com o Brasil que remontam ao Império e que foram mantidas após a proclamação da República (TENÓRIO, 1976, p. 415-416). No entanto, carecia de um tratado que regulamentasse as relações entre a Igreja Católica e o Brasil. Em razão disso e após longa negociação, o Brasil e a Santa Sé firmaram o Acordo Relativo ao Estatuto Jurídico da Igreja Católica no Brasil, ratificado em 10 de dezembro de 2009 e promulgado por decreto do Poder Executivo brasileiro em 11 de fevereiro de 2010, Decreto $\mathrm{n}$. 7.107.

\footnotetext{
${ }^{18}$ Sobre o Tratado de Latrão, o Estado da Cidade do Vaticano e a soberania da Santa Sé ver: DE LA BRIÈRE (1930, p. 113-166).

${ }^{19}$ Mesmo antes de 1929 e após a unificação da Itália e a conquista de Roma pelo Rei da Sardenha, o Papa manteve a sua soberania e a "independência e o livre exercício da autoridade especial da Santa Sé", reconhecida conforme a Lei das Garantias de 13 de maio de 1871 promulgada pelo Reino da Itália. Mazzuoli (2012, p. 441448) frisa que a Santa Sé sempre foi soberana e reconhecida por todos os Estados como tal, mesmo pelos Estados que não professam a religião católica.
} 
Examinando-se o Acordo Brasil - Santa Sé ${ }^{20}$, constata-se que o Brasil reconhece o Direito Canônico como o Direito da Santa Sé enquanto entidade soberana, capaz de coercitivamente impor o seu ordenamento jurídico aos seus jurisdicionados, assegurando, portanto, a sua aplicação nas hipóteses reconhecidas pelo Direito Internacional Privado brasileiro $^{21}$ como de aplicação do direito estrangeiro ${ }^{22}$, e em outras hipóteses previstas no tratado. Assim como reconhece expressamente a jurisdição eclesiástica da Santa Sé em matéria matrimonial, e dispõe sobre a homologação de sentença eclesiástica como sentença estrangeira para o seu reconhecimento e execução no Brasil.

Logo ao iniciar o Acordo, no primeiro considerando do preâmbulo, consta expressamente o reconhecimento da Santa Sé como suprema autoridade da Igreja Católica Apostólica Romana, "regida pelo Direito Canônico". Segundo o artigo 31 da Convenção de Viena sobre Direitos dos Tratados, promulgada no Brasil pelo Decreto n. 7.030 de 2009, o preâmbulo de um tratado é importante para a sua adequada interpretação e aplicação. Assim sendo, vislumbra-se que para o Brasil não há dúvida quanto a natureza jurídica do Direito Canônico e a sua qualidade de direito estrangeiro.

Também no quarto parágrafo do preâmbulo fica evidente a equiparação entre o direito brasileiro e o canônico ${ }^{23}$ :

Baseando-se, a Santa Sé, nos documentos do Concílio Vaticano II e no Código de Direito Canônico, e a República Federativa do Brasil, no seu ordenamento jurídico;

$\mathrm{Na}$ parte dispositiva do tratado pode ser destacado o artigo $3^{\circ}$, que estipula sobre o reconhecimento da personalidade jurídica da Igreja Católica "e de todas as Instituições Eclesiásticas que possuem tal personalidade em conformidade com o direito canônico". Tal dispositivo reconhece ao Direito da Santa Sé capacidade extraterritorial de produzir efeitos no Brasil no que tange a atribuição de personalidade jurídica às instituições eclesiásticas.

Cite-se, ainda, o disposto no artigo 12 do Acordo, que estabelece que "o casamento celebrado em conformidade com as leis canônicas, que atender também às exigências estabelecidas pelo direito brasileiro para contrair casamento, produz os efeitos civis [...]”, assim como o seu importantíssimo parágrafo $1^{\circ}$.

\footnotetext{
${ }^{20}$ Para uma visão geral do Acordo e seus dispositivos ver Baldisseri e Martins Filho, (coordenadores), 2012, LTr).

${ }^{21}$ Nesse sentido, ver Rodas, Direito Canônico é aplicável no Brasil, por força de tratado ou de regras conflituais. Consultor Jurídico.10/12/2015, 8h. Apreendido em <conjur.com.br>.

${ }^{22}$ As normas de Direito Internacional Privado brasileiro estão dispostas, especialmente, na Lei de Introdução às Normas do Direito Brasileiro.

${ }^{23}$ Nesse sentido, Baldisseri (2011, p. 97).
} 
O parágrafo $1^{\circ}$. do artigo 12 trata de questão diretamente ligada a circulação internacional de sentenças, ou seja, a possibilidade da sentença ou decisão judicial transitada em julgado e prolatada em uma jurisdição estrangeira produzir efeitos e ser executada em outra jurisdição. $\mathrm{O}$ citado parágrafo está assim redigido:

$\S 1^{\circ}$. A homologação das sentenças eclesiásticas em matéria matrimonial, confirmadas pelo órgão de controle superior da Santa Sé, será efetuada nos termos da legislação brasileira sobre homologação de sentença estrangeiras.

A questão é da maior importância no Direito Internacional Privado e decorre naturalmente da possibilidade de um Estado aplicar o direito estrangeiro em sua jurisdição. Se um Estado permite a aplicação do direito estrangeiro em determinadas relações jurídicas pluriconectadas, ou seja, conectadas a mais de um ordenamento jurídico nacional, é natural que para o bem da Justiça proporcione a possibilidade de reconhecimento e execução de sentença estrangeira, desde que respeitados determinados critérios importantes para o foro, especialmente os concernentes a ordem pública.

No Brasil, as sentenças estrangeiras para produzirem efeitos jurídicos devem ser homologadas pelo Superior Tribunal de Justiça - STJ, conforme artigo 105, I, “i”, da Constituição Federal. O rito processual está previsto nos artigos 960 a 965 do Código de Processo Civil, no Regimento Interno do Superior Tribunal de Justiça e na Resolução n. 9 de 2005 do citado tribunal ${ }^{24}$.

A primeira sentença estrangeira sujeita ao processo de homologação com fulcro no parágrafo $1^{\circ}$. do art. 12 do Acordo Brasil - Santa Sé foi reconhecida como válida para produzir plenamente efeitos no Brasil, sem qualquer óbice. A ementa está redigida nos seguintes termos ${ }^{25}$ :

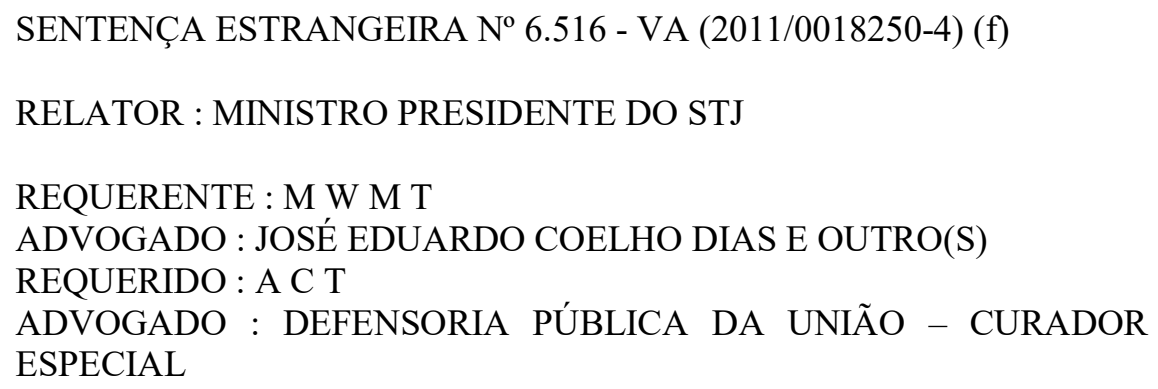

\footnotetext{
${ }^{24}$ Sobre homologação de sentença estrangeira ver, entre outros, Araujo (2016, p.303-332) e Dolinger e Tiburcio (2016, p. 613-618).

${ }_{25}$ Acessado e apreendido diretamente na página do Superior Tribunal de Justiça em 08 de abril de 2017, $<$ http://www.stj.jus.br/SCON/decisoes/toc.jsp?processo=006516.NUM.\&\&tipo_visualizacao=RESUMO\&b= DTXT\&thesaurus $=$ JURIDICO\&p $=$ true $>$.
} 
Trata-se de pedido de homologação da sentença de anulação do matrimônio do requerente, $\mathrm{M}$ W M T, com a requerida, A C DA S, brasileiros, qualificados nos autos, proferida pelo eg. Tribunal Eclesiástico Interdiocesano de Vitória, Espírito Santo (fl. 6), confirmada por decreto do Tribunal Eclesiástico Interdiocesano de Aparecida, São Paulo (fl. 22), bem como pelo Supremo Tribunal da Assinatura Apostólica, no Vaticano (fl. 160).

A d. Defensoria Pública da União, na qualidade de curador especial da requerida, e a d. Subprocuradoria-Geral da República manifestaram-se, às fls. 82 e 166 , favoravelmente ao pedido.

É o breve relatório.

Decido.

Destaco, inicialmente, ser este o primeiro pedido de homologação de sentença eclesiástica processado em conformidade com o disposto no acordo firmado entre o Brasil e a Santa Sé, relativo ao Estatuto Jurídico da Igreja Católica no Brasil (Decreto 7.107/2010).

De acordo com o referido decreto, as decisões eclesiásticas confirmadas pelo órgão superior de controle da Santa Sé são consideradas sentenças estrangeiras para efeitos de homologação.

Assim, verifico que os pressupostos indispensáveis ao deferimento do pleito foram observados. Ademais, a pretensão não ofende a soberania nacional, a ordem pública nem os bons costumes (art. 17 da LINDB e arts. $5^{\circ}$ e $6^{\circ}$ da Resolução n. 9 de 2005 do Superior Tribunal de Justiça).

Diante disso, homologo o título judicial estrangeiro.

Expeça-se a carta de sentença.

P. e I.

Brasília, 16 de maio de 2013.

MINISTRO FELIX FISCHER

Presidente

A decisão do Superior Tribunal de Justiça homologando a primeira sentença eclesiástica após o Acordo Brasil - Santa Sé estar em vigor, apesar da sua simplicidade, deixa evidente o reconhecimento pelo Brasil da jurisdição da Santa Sé, da autoridade de seus juízes, e, consequentemente, da validade, coercibilidade e eficácia do seu Direito Canônico, apto e capaz de desconstituir uma relação jurídica constituída no plano religioso e também secular ${ }^{26}$.

Por todo o exposto neste tópico, provado está o caráter jurídico do Direito Canônico por comungar evidentemente das características marcantes do Direito: a heteronomia, a coercibilidade e a bilateralidade atributiva.

${ }^{26}$ Outras decisões já foram proferidas, inclusive reconhecendo a constitucionalidade do Acordo Brasil-Santa Sé e a adequação do Direito Canônico às garantias fundamentais de natureza processual, como o respeito ao princípio da igualdade, ao contraditório e a ampla defesa. Nesse sentido julgado da Corte Especial do Superior Tribunal de Justiça, SEC 11.962-EX, Rel. Min. Felix Fischer, j. 4/11/2015, DJe 25/11/2015. 
Consequentemente, não há qualquer dúvida de que Direito Canônico é ramo da Ciência do Direito e, assim sendo, saber contido pela área de conhecimento do Programa de PósGraduação em Direito Stricto Sensu nas universidades brasileiras.

\section{O procedimento para o reconhecimento de diploma de pós-graduação em Direito}

\section{Canônico à luz do artigo 18 da Resolução CES/CNE n. 3 de 2016}

O artigo 18 da Resolução n. 3 CES/CNE/2016 está assim redigido:

Art. 18. O processo de reconhecimento dar-se-á a partir da avaliação de mérito das condições de organização acadêmica do curso e, quando for o caso, do desempenho global da instituição ofertante, especialmente na atividade de pesquisa.

$\S 1^{\circ}$. O processo de avaliação deverá considerar as características do curso estrangeiro, tais como a organização institucional da pesquisa acadêmica no âmbito da pós-graduação stricto sensu, a forma de avaliação do (a) candidato (a) para integralização do curso e o processo de orientação e defesa da tese ou dissertação.

$\S 2^{\circ}$. O processo de avaliação deverá considerar diplomas resultantes de cursos com características curriculares e de organização de pesquisa distintas dos programas e cursos stricto sensu ofertados pela universidade responsável pelo reconhecimento.

$\S 3^{\circ}$. Para o cumprimento do disposto no parágrafo anterior, a universidade poderá, a seu critério, organizar comitês de avaliação com a participação de professores e pesquisadores externos ao corpo docente institucional que possuam perfil acadêmico-científico adequado à avaliação do processo específico.

$\S 4^{\circ}$. O (A) requerente do reconhecimento de diploma estrangeiro deverá atender às solicitações de informação da universidade reconhecedora, além da apresentação dos seguintes documentos:

I - cadastro contendo os dados pessoais e, quando for o caso, informações acerca de vinculação institucional que mantenha no Brasil;

II - cópia do diploma devidamente registrado pela instituição responsável pela diplomação, de acordo com a legislação vigente no país de origem e autenticado por autoridade consular competente;

III - exemplar da tese ou dissertação com registro de aprovação da banca examinadora, autenticada pela instituição de origem e por autoridade consular competente, com cópia em arquivo digital em formato compatível, acompanhada dos seguintes documentos:

a) ata ou documento oficial da instituição de origem, contendo a data da defesa, o título do trabalho, a sua aprovação e conceitos outorgados, devidamente autenticados por autoridade consular competente; e

b) nomes dos participantes da banca examinadora e do (a) orientador(a) acompanhados dos respectivos currículos resumidos, com indicação de site contendo os currículos completos; 
IV - cópia do histórico escolar, autenticado pela instituição estrangeira responsável pela diplomação e pela autoridade consular competente, descrevendo as disciplinas ou atividades cursadas, com os respectivos períodos e carga horária total, indicando a frequência e o resultado das avaliações em cada disciplina;

V - descrição resumida das atividades de pesquisa realizadas e cópia impressa ou em endereço eletrônico dos trabalhos científicos decorrentes da dissertação ou tese, publicados e/ou apresentados em congressos ou reuniões acadêmicocientíficas, indicando a (s) autoria(s), o nome do periódico e a data da publicação; e

VI - resultados da avaliação externa do curso ou programa de pós-graduação da instituição, quando houver e tiver sido realizada por instituições públicas ou devidamente acreditadas no país de origem, e outras informações existentes acerca da reputação do programa indicadas em documentos, relatórios ou reportagens.

$\S 5^{\circ}$ Caberá à universidade responsável pela análise de reconhecimento solicitar, quando julgar necessário, ao (à) requerente a tradução da documentação prevista no $\S 4^{\circ}$.

$\S 6^{\circ} \mathrm{O}$ disposto no parágrafo anterior não se aplica às línguas francas utilizadas no ambiente de trabalho da pesquisa institucional, tais como o inglês, o francês e o espanhol.

$\S 7^{\circ} \mathrm{O}$ tempo de validade da documentação acadêmica, a que se refere o $\S 4^{\circ}$, será o mesmo adotado pela legislação brasileira.

$\S 8^{\circ} \mathrm{O}$ reconhecimento do diploma, quando ocorrer, deverá preservar a nomenclatura do título do diploma original.

$\S 9^{\circ}$ A universidade responsável pelo reconhecimento deverá apostilar o diploma, reconhecendo como equivalente a mestrado ou a doutorado e, quando for o caso, constar a correspondência entre o título original com a nomenclatura adotada no Brasil.

Como se verifica do extenso artigo da Resolução n. 3 CES/CNE/2016, acima transcrito, para o reconhecimento do diploma de pós-graduação stricto sensu estrangeiro é necessário o exame de condições específicas relacionadas ao curso, ao programa de pós-graduação e a universidade que concedeu o grau acadêmico, e ainda ao exame específico e objetivo de documentos referentes ao Requerente.

3.1. A pós-graduação em Direito Canônico nas instituições de educação superior e pesquisa vinculadas a Santa Sé

A Santa Sé localiza-se territorialmente no Estado da Cidade do Vaticano, em Roma, Itália, Europa, como é notório, e, como ente soberano, ratificou diversos tratados objetivando adequar-se ao desiderato europeu de construção de um espaço comum para a educação superior, 
especialmente a European Cultural Convention ${ }^{27}$, a European Convention on the Academic Recognition of University Qualifications ${ }^{28} \mathrm{e}$, especialmente, a Convention on the Recognition of Qualifications concerning Higher Education in the European Region e aderiu ao Processo de Bologna para a construção de um espaço europeu integrado de alto nível para a educação superior.

O Processo de Bologna visa à construção do Espaço Europeu de Educação Superior. O objetivo é harmonizar o sistema de educação superior e a atribuição de graus e títulos acadêmicos pelos Estados associados, de modo a permitir a comparação e a equiparação dos cursos superiores entre os países membros, inclusive para fins de mútuo reconhecimento dos direitos decorrentes dos graus, títulos e diplomas universitários concedidos ${ }^{29}$.

O Processo de Bologna adota o sistema de três ciclos ${ }^{30}$ de estudos acadêmicos de nível superior, podendo o segundo ciclo ser equivalente ao mestrado (dependendo de quantos créditos o estudante cumprir no primeiro e no segundo ciclo), e sendo o terceiro ciclo equivalente ao doutorado. No citado sistema de três ciclos, o segundo ciclo deve ter de 60-120 ECTS (European Credit Transfer and Accumulation System $)^{31}$ e o estudante deve apresentar uma dissertação. O terceiro ciclo corresponde ao doutorado e não há créditos obrigatórios ou disciplinas obrigatórias a serem cursadas, exige-se tese doutoral ${ }^{32}$.

Por sua vez, no Livro III, Título III, Capítulos II e III do Código de Direito Canônico, a Santa Sé trata das instituições de ensino superior. O Código como lei geral complementa a Constituição Apostólica Ex Corde Ecclesiae, de 15 de agosto de 1990, destinada às universidades católicas, e também complementa a Constituição Apostólica Sapientia Christiana promulgada junto com o regulamento da Sagrada Congregação para a Educação Católica em 15 de abril de 1979, destinada às universidades eclesiásticas.

As universidades católicas são instituições de educação superior e pesquisa dedicadas às diversas áreas do conhecimento, mas "levando-se em conta a doutrina católica" (Código de Direito Canônico - CDC, Cân. 809). A ereção de uma universidade católica compete às

\footnotetext{
27 Ser parte desta convenção é sine qua non para participar do processo de uniformização das regras para a educação superior e para a concessão de graus acadêmicos, cf. http://www.ehea.info/pid34249/members.html. ${ }^{28} \mathrm{http} / /$ www.coe.int/en/web/conventions/full-list/-conventions/treaty/country/HOL?p_auth=XUmxKksJ.

${ }^{29} \mathrm{Ver}, \mathrm{http}: / / w w w . e h e a . i n f o /$.

${ }^{30} \mathrm{Cf}$. http://www.ehea.info/pid34438/three-cycle-system.html.

${ }^{31}$ O ECTS também propicia ao estudante e as instituições de ensino um critério fixo para avaliar e determinar o número de horas dedicadas às disciplinas cursadas e, assim, possibilizar a sua contabilização em caso de retorno de estudantes estrangeiros ao país de origem para aproveitamento de estudos ou para a revalidação e reconhecimento de diplomas de graduação e pós-graduação stricto sensu.

${ }^{32} \mathrm{Cf}$. http://www.ehea.info/pid34438/three-cycle-system.html
} 
autoridades eclesiásticas em geral, mas especialmente aos Bispos diocesanos e às organizações religiosas.

As universidades e faculdades eclesiásticas são aquelas dedicadas a estudar e a "pesquisar as disciplinas sagradas ou as com elas ligadas, e para formar cientificamente os estudantes nessas disciplinas" (CDC, Cân. 815). Essas faculdades e universidades eclesiásticas são erigidas pela Santa Sé ou dependem de sua aprovação expressa, e são submetidas a sua supervisão direta, conforme Cân. 816 do Código de Direito Canônico. Somente essas instituições conferem graus acadêmicos com efeitos canônicos na Igreja Católica e em nome da Santa Sé, segundo o Cân. 817 do CDC e tópico VI do Proêmio e arts. $2^{\circ}$. e $6^{\circ}$. da Sapientia Christiana. O art. 34 do Regulamento da Sagrada Congregação para a Educação Católica é claro ao dispor que os graus acadêmicos conferidos por faculdades e universidades eclesiásticas o são em nome do Sumo Pontífice.

A concessão do título pontifícia (o) é outorgado especialmente e diretamente pela Santa $\mathrm{Sé}^{33}$, mas não é exclusivo das universidades eclesiásticas, também pode ser concedido às universidades católicas. O título dá especial dignidade à instituição de educação superior, tanto que, dentre aproximadamente mil e oitocentas universidades católicas no mundo, apenas poucas ostentam tal título ${ }^{34}$.

São consideradas disciplinas sagradas e objeto da atividade de ensino das faculdades e universidades eclesiásticas as ministradas pelas faculdades de Teologia, Direito Canônico (regulada a partir do artigo 75 da Constituição Apostólica Sapientia Christiana ${ }^{35}$ ) e Filosofia.

A formação em Direito Canônico exige prévia graduação em Faculdade de Teologia e, aos que não cursaram Teologia, mesmo aos que sejam graduados em Direito, cursar o primeiro ciclo de dois anos em Teologia com carga mínima de cento e vinte ECTS. O segundo ciclo exige cursar mais 180 ECTS de disciplinas por cerca de aproximadamente três anos e apresentar uma dissertação orientada por um professor ${ }^{36}$. Para o terceiro ciclo, ou doutorado, não há exigência de completar-se carga horária com créditos específicos, mas a duração mínima é de um ano de pesquisas $^{37}$, e exige-se pesquisa científica que contribua para o progresso da Ciência que tenha

\footnotetext{
${ }^{33}$ Segundo HORTAL, in SANTA SÉ, Código de Direito Canônico (2008, nota ao Cân. 808, p. 218).

${ }^{34}$ Cf. PONTIFÍCIA UNIVERSIDADE CATÓLICA DE GOIÁS. Reitor Prof. Wolmir Therezio Amado. Esclarecimentos do Reitor sobre o reconhecimento pontifício da Católica como PUC Goiás, 16 de setembro de 2009, in http://www.ucg.br/ucg/avisos/0249.asp, apreendido em 09 de fevereiro de 2017.

35 Disponível em < http://w2.vatican.va/content/john-paul-ii/pt/apost_constitutions/documents/hf_jpii_apc_15041979_sapientia-christiana.html > apreendida em 10 de março de 2018.

$36 \quad$ Cf. $<$ http://www.educatio.va/content/cec/it/studi-superiori-della-santa-sede/quadro-nazionale-dellequalifiche/qualifications-framework/diritto-canonico.html $>$ apreendido em 10 de março de 2018.

37 PONTIFÍCIO INSTITUTO SUPERIOR DE DIREITO CANÔNICO DO RIO DE JANEIRO. Guia Acadêmico. Sem data. Rio de Janeiro, p. 10, disponível em http://pisdc.com.br/site/wpcontent/uploads/2010/10/Guia-Academico.pdf.,p.16.
} 
sido elaborada sob a orientação de um professor, publicamente defendida, colegialmente aprovada e, ainda, que tenha sido publicada ao menos a sua parte principal (Art. 49, parágrafo $3^{\circ}$., Constituição Apostólica Sapientia Christiana).

Entre as universidades eclesiásticas, para fins de perscrutar-se o mérito sobre as condições de organização acadêmica do curso de pós-graduação stricto sensu em Direito Canônico e do desempenho global da instituição ofertante, inclusive na atividade de pesquisa como exige o artigo 18 da Resolução n. 3 CES/CNE acima citada, e se estabelecer um paradigma, elege-se a Pontifícia Universidade Gregoriana de Roma - PUG.

A PUG é uma das mais antigas universidades eclesiásticas ${ }^{38}$ erigida pela Santa Sé, situada na cidade de Roma, mas beneficiada expressamente pelo Tratado de Latrão ${ }^{39}$, firmado entre a Santa Sé e a Itália, Anexo 3, com imunidade diplomática e fiscal (DE LA BRIÈRE, 1930, p.136).

Deve ser destacado que a Pontifícia Universidade Gregoriana de Roma - PUG é instituição de ensino e pesquisa renomada, ente central da Santa $\mathrm{Sé}^{40}$, fundada em 1556. Outrossim, a PUG apresenta uma particularidade que recomenda ainda mais a sua escolha como instituição de ensino paradigma neste estudo: oferece a possibilidade do curso de mestrado em Direito Canônico ser trilhado pelo aluno integralmente no Brasil há mais de trinta anos, na sede do Pontifício Instituto Superior de Direito Canônico - PISDC situado no Município do Rio de Janeiro, em razão da agregação do PISDC à Pontifícia Universidade Gregoriana de Roma (PUG).

O sistema acadêmico eclesiástico da Santa Sé prevê que institutos eclesiásticos de estudos superiores sejam coligados a faculdades ou universidades eclesiásticas para que, observadas às regras dessas faculdades ou universidades e às da Santa Sé na ordenação dos estudos, obtenham os estudantes desses institutos os graus acadêmicos conferidos por essas faculdades e universidades. Agregação é o nomen iuris para essa citada coligação entre a

\footnotetext{
${ }^{38} \mathrm{Cf}$. http://www.unigre.it/Univ/chi_siamo_it.php.

${ }^{39}$ O Tratado de Latrão é composto por acordos firmados entre a Santa Sé e a Itália, datados de 11 de fevereiro de 1929, que puseram fim a "Questão Romana" e fundaram o Estado da Cidade do Vaticano. No processo de unificação da Itália, os Estados Pontifícios e a cidade de Roma, território da Santa Sé, foram invadidos pelas tropas do Rei da Sardenha e anexados definitivamente em 1870, o que levou o Papa Pio IX a se refugiar no Palácio do Vaticano e a não reconhecer a soberania italiana. Pelos acordos de Latrão, a Santa Sé aceita a perda dos Estados Pontifícios e da cidade de Roma, decorrente da unificação italiana, reconhece o Reino da Itália, e, em compensação, entre outras vantagens, mantém a soberania sobre os 44 hectares do Vaticano - originalmente uma localidade na cidade de Roma -, reconhecidos pela Itália como território do Estado da Cidade do Vaticano, sobre o Palácio de Castelgandolfo, sobre as Basílicas de São João de Latrão, Santa Maria Maior e São Paulo Extramuros situadas na cidade de Roma. Os acordos também concedem imunidades diplomáticas, fiscais, compensações financeiras e inclui matérias de interesse religioso. Sobre o assunto ver, também, MELLO (2004, p. 562-563) e ACCIOLY, SILVA e CASELLA (2009, p. 552-553).

${ }^{40} \mathrm{Cf}$. http://www.unigre.it/Univ/su/PUG_esenzione_it.php.
} 
instituição de ensino superior romana com institutos de estudos superiores ao nível de primeiro e segundo ciclo de estudos (bacharelado e mestrado) ${ }^{41}$.

A PUG observa o Processo e o Acordo de Bologna ${ }^{42}$ para a construção de um espaço europeu integrado de alto nível para a educação superior, e, por sua vez, a Faculdade de Direito Canônico da PUG foi fundada em 1876, é renomadíssima, e dedica-se a estudar e a pesquisar a Ciência Jurídica Canônica, ordenamento da própria Santa Sé, o que faz com expertise incomparável vez que é uma Faculdade dedicada a um ramo do Direito ligado umbilicalmente a sua própria existência como ente central da Santa Sé e da Igreja Católica Apostólica Romana.

As informações sobre a Faculdade e sobre o Curso de Direito Canônico estão disponíveis em várias línguas em sítio próprio ${ }^{43}$, e especificamente se afirma a adequação do seu currículo ao sistema de três ciclos estabelecido pelo Processo de Bologna. O segundo ciclo, com defesa de uma dissertação (em italiano "Tesi di licenza sotto la guida di um professore",44), equivale ao segundo ciclo pelo Processo de Bologna e se adequa ao estabelecido no Brasil para o grau de mestrado, como será demonstrado. O terceiro ciclo equivale ao doutorado.

O segundo ciclo do Processo de Bologna, (que pode corresponder ao curso de mestrado ${ }^{45}$ ), implica em carga horária total de atividades acadêmicas que varia em média de 90 a 120 ECTS, não podendo ser inferior a 60 ECTS. Cada crédito ECTS corresponde a 25-30 horas de atividades acadêmicas, o que gera uma carga de trabalho de 1.500 a 1.800 horas por ano, conforme o ECTS User's Guide p. 10-19, publicado pela Comissão Europeia em $2015^{46}$.

A carga horária contada em créditos e horas de atividades acadêmicas a serem cursadas pelos alunos do curso equivalente ao mestrado em Direito Canônico da PUG, atende aos requisitos do Processo de Bologna para os estudos do segundo ciclo. Os alunos que não cursaram Faculdade de Teologia obrigatoriamente cursam também o primeiro ciclo, com dois anos de duração, como se pode constatar do Programma degli Studi 2016-2017 ${ }^{47}$, conforme determinado na Constituição Apostólica Sapientia Christiana e já exposto mais acima.

41 Cf. explana a Congregazione per l'Educazione Cattolica della Santa Sede em http://www.educatio.va/content/cec/it/studi-superiori-della-santa-sede.html, apreendido em 09 de fevereiro de 2017. Nesse sentido também, HORTAL in SANTA SÉ. Código de Direito Canônico, 2008, nota ao Cân. 816, p. 219).

${ }^{42} \mathrm{Cf} .<\mathrm{http}: / /$ www.unigre.it/Studenti/processo_bologna_en.php $>$.

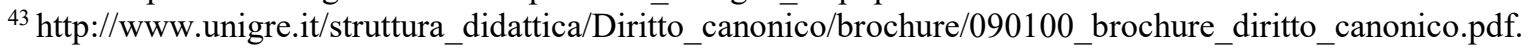

${ }^{44} \mathrm{Cf}$. http://www.unigre.it/struttura_didattica/Diritto_canonico/specifico/brochure_diritto_canonico_en.php.

45 Sobre as dificuldades na equiparação de diplomas e graus acadêmicos estrangeiros aos brasileiros ver VARELLA e LIMA, (2012, p. 143-161, doi: 10.5102/rbpp.v.2i1.1814).

46 Disponível in http://ec.europa.eu/dgs/education_culture/repository/education/ects/users-guide/docs/ectsusers-guide_en.pdf.

47 Disponível no sítio da Faculdade de Direito Canônico da Pontifícia Universidade Gregoriana in http://www.unigre.it/struttura_didattica/Diritto_canonico/documenti/programma_diritto_canonico_201617_v2.pdf. 
O acesso ao doutorado exige a conclusão do curso de mestrado com sucesso e aprovação pela banca examinadora da dissertação com grau superior a 8 (oito) e magna cum laude ${ }^{48}$, domínio das línguas italiana e latina, mais uma neolatina, e ainda o inglês ou o alemão ${ }^{49}$. O curso de doutorado pode ser "Ordinário" ou com especialização em Giurisprudenza duração de aproximadamente seis semestres e com três disciplinas a serem cursadas, além da defesa da tese ${ }^{51}$.

A carga horária exigida no Processo de Bologna é compatível com a carga horária dos programas de pós-graduação stricto sensu em Direito mais qualificados do Brasil, como, por exemplo, o da Universidade de São Paulo - USP ${ }^{52}$.

A USP exige dos mestrandos em Direito a integralização de noventa e oito créditos equivalentes a mil, quatrocentos e setenta horas de atividades acadêmicas durante o curso; para os doutorandos com títulos de Mestre pela USP cento e cinquenta e seis créditos, equivalentes a duas mil, trezentos e quarenta horas (computados os créditos já integralizados no mestrado); e no caso de doutorado direto, ou seja, sem que o estudante já tenha o grau de Mestre, a integralização total de cento e noventa e seis créditos correspondentes a duas mil novecentos e quarenta horas. Parte significativa do total desses créditos são integralizados pela dedicação à pesquisa e redação da dissertação de mestrado ou da tese de doutorado: no mestrado, 58 créditos são atribuídos para a elaboração da dissertação; e no doutorado, 116 créditos são atribuídos à elaboração da tese ${ }^{53}$.

48 Para detalhes ver la brochure della Facoltà di Diritto Canonico, disponível in $<$ http://www.unigre.it/struttura_didattica/Diritto_canonico/specifico/brochure_diritto_canonico_it.php $>$ apreendida em 30 de janeiro de 2017.

${ }^{49} \mathrm{Cf} .<$ https://www.unigre.it/struttura_didattica/Diritto_canonico/specifico/terzo_ciclo_ordinario_it.php $>$ apreendido em 01 de setembro de 2018.

${ }^{50}$ Trata-se de uma especialização em prática forense romana, com estudo de disciplinas e temas mais comuns judicialmente, análise de casos judicias e jurisprudência dos tribunais eclesiásticos.

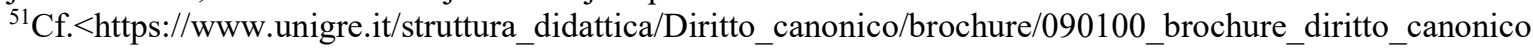
.pdf $>$ apreendido em 01.09.2018.

${ }^{52}$ A pós-graduação stricto sensu em Direito da USP possui posição consolidada na nota 6 de avaliação do Capes. A nota máxima é 7, mas nenhum programa de pós-graduação em Direito no Brasil atingiu a nota 7 até a data do relatório no ano de 2013. Somente oito programas de pós-graduação em Direito receberam nota 6 , que significa produção científica de nível e referência internacional, formação de professores com forte inserção nas universidades brasileiras em todas as regiões do país, renome de seus professores em nível nacional e internacional, e, no caso da USP, forte inserção na vida política e jurídica do país, cf. Relatório de Avaliação Trienal 2013 da Coordenação de Aperfeiçoamento de Pessoal de Nível Superior - CAPES, do Ministério da Educação da República Federativa do Brasil, p. 25 e s. in https://docs.google.com/viewer?a=v\&pid=sites\&srcid=Y2FwZXMuZ292LmJyfHRyaWVuYWwtMjAxM3x neDo5NWRiMjB1OGY2ZDQ5ODA. Ver também http://www.prpg.usp.br/index.php/pt-br/faca-pos-nausp/programas-de-pos-graduacao/215-direito-fd>, apreendido em 30 de janeiro de 2017.

53 Cf. Normas da Comissão Coordenadora do Programa Direito, disponível in http://www.prpg.usp.br/uploads/norma-CCP-Direito-FD.pdf, apreendido em 30 de janeiro de 2017. 
O diploma expedido pela PUG é escrito em latim, língua oficial da Santa Sé, atribui ao seu beneficiário o título de "Licentiatum in Iure Canonico", o que equivale ao título de Mestre, considerando a graduação prévia em Teologia ou Direito (somada a carga horária a ser cumprida no primeiro ciclo para os que não estudaram Teologia) e a carga horária do Curso, o Acordo de Bolonha e a legislação que rege a concessão do título ou grau. O título de Doutor pode, opcionalmente, vir agregado com especialização em Giurisprudenza. Frise-se que esses títulos são legalmente reconhecidos pela Congregação para a Educação Católica (para as Instituições de Estudos $)^{54}$, órgão máximo da Santa Sé para a educação católica, atribuindo ao seu detentor grau canônico, conforme já esclarecido anteriormente. Sendo assim, o diploma emitido pela PUG atende a todas as exigências do ordenamento jurídico da Santa Sé para a sua plena validade e efeitos de direito, e tem plena equivalência com os brasileiros de modo a permitir o seu reconhecimento.

Portanto, considerando o Acordo Brasil - Santa Sé, já citado em outro momento, no qual o artigo $9^{\circ}$. dispõe sobre o reconhecimento recíproco de títulos e qualificações em nível de graduação e pós-graduação desde que atendidas às exigências dos ordenamentos jurídicos brasileiro e da Santa Sé, não há óbice legal para que o título e grau concedido pelas universidades e faculdades eclesiásticas da Santa Sé, decorrentes de estudos de pós-graduação stricto sensu em Direito Canônico sejam reconhecidos como correspondentes aos de Mestre e Doutor em Direito e produzam os seus naturais e jurídicos efeitos no Brasil.

Questão importante a ser examinada é sobre a possibilidade do curso de pós-graduação stricto sensu em Direito Canônico ser ministrado validamente em solo brasileiro por Instituição de Ensino da Santa Sé, ou sob seu patrocínio.

3.1.1. Curso de pós-graduação stricto sensu em Direito Canônico ministrado no Brasil por universidade eclesiástica da Santa Sé.

Esse problema é relevantíssimo, considerando que muitos egressos da pós-graduação stricto sensu em Direito Canônico com títulos de "Licentitatum in Iure Canonico" e diplomas expedidos pela PUG estudaram e pesquisaram no Brasil, mais precisamente no Pontifício Instituto Superior de Direito Canônico - PISDC ${ }^{55}$, fundado e administrado pela Arquidiocese do Rio de Janeiro e agregado à PUG com a autorização da Santa Sé.

Frise-se que existem outros institutos de estudos de Direito Canônico erigidos no Brasil e vinculados a universidades eclesiásticas estrangeiras, como o recém-fundado Instituto de

54 A tradução para o português é da própria Santa Sé, conforme sítio na internet: < http://www.vatican.va/roman_curia/congregations/ccatheduc/index_po.htm $>$ apreendido em 22 de fevereiro de 2017.

${ }^{55}$ Não há Curso de Doutorado no PISDC até 21 de setembro de 2018, embora haja estudos sobre o assunto. 
Direito Canônico Santa Catarina, ereto, fundado e vinculado à Arquidiocese de Florianópolis e à Pontifícia Universidade Lateranense em 16 de julho de $2016^{56}$. No entanto, o PISDC é, senão o mais antigo, um dos mais antigos institutos sediados no Brasil dedicado aos estudos de Direito Canônico, agregado a uma universidade eclesiástica da Santa Sé, no intuito de conceder ao corpo discente o grau de Mestre, e, também por isso, é o ente paradigma na questão sub examine.

A Resolução CNE/CES n. 1 de 2001 e ainda em vigor ${ }^{57}$ estabelece normas sobre o funcionamento dos cursos de pós-graduação em geral. No seu artigo $2^{\circ}$. dispõe que os cursos de pós-graduação stricto sensu oferecidos por instituições de ensino estrangeiras em associação com instituições de ensino brasileiras obedecem às mesmas exigências de autorização, reconhecimento e renovação periódica de reconhecimento estabelecidas naquela resolução para instituições de educação superior brasileiras.

Ocorre que o PISDC é instituição eclesiástica de ensino da Santa Sé, apesar de estar em solo brasileiro, beneficiada pelo Acordo Brasil - Santa Sé, pelo Código Civil em vigor e pela Lei de Introdução às Normas do Direito Brasileiro, logo não se adequa aos termos da Resolução CNE/CES n. 1 de 2001 e não se sujeita às suas regras de natureza meramente regulamentar ${ }^{58}$.

A Congregação para a Educação Católica, Dicastério ${ }^{59}$ da Cúria Romana ${ }^{60}$, em 30 de novembro de 1984, promulgou o decreto de ereção pontifícia do Instituto Superior de Direito Canônico do Rio de Janeiro, confiando-o permanentemente à administração direta do Ordinário Diocesano do Rio de Janeiro e agregando-o à Faculdade de Direito Canônico da Pontifícia Universidade Gregoriana de Roma ${ }^{61}$. O Grão-Chanceler é o Prefeito da Congregação para a Educação Católica e o Chanceler Delegado é o Arcebispo de São Sebastião do Rio de Janeiro ${ }^{62}$. Assim sendo, o citado instituto é ente pertencente à Santa Sé e observante das regras universais para oferecimento do Curso de Mestrado em Direito Canônico, disciplinado pela Constituição

\footnotetext{
${ }^{56}$ Ver: http://isdcsc.org.br/institucional/, acesso em 17 de março de 2017.

57 A Resolução CNE/CES no.3 de 2016, em seu artigo 32, revogou expressamente apenas o artigo $4^{\circ}$. da Resolução CNE/CES no.1 de 2001.

${ }^{58}$ Regulamentos não podem restringir ou ampliar direitos assegurados por lei ou por tratado, pois visam propiciar a execução da lei ou do tratado (vide artigos 87, II, e 84, IV, da Constituição Federal). Frise-se que a jurisprudência do Supremo Tribunal Federal e do Superior Tribunal de Justiça é pacífica ao atribuir aos tratados internacionais status hierárquico supralegal, ou seja, superior a lei.

${ }^{59}$ Os Dicastérios são órgãos da Santa Sé que auxiliam o Papa no governo da Igreja e do Estado, vide: http://www.vatican.va/roman_curia/congregations/ccatheduc/documents/rc_con_ccatheduc_20051996_profil e_en.html, e, principalmente, a Constituição Apostólica Pastor Bonus Sobre a Cúria Romana, disponível em http://paroquiasantoantoniopatos.com.br/admin/documentos/Constitui\%C3\%A7ao-Apostolica-PASTORBONUS-sobre-a-Curia-Romana.pdf.

${ }^{60} \mathrm{Cf}$. pode ser constatado em http://www.vatican.va/roman_curia/congregations/ccatheduc/index_po.htm.

${ }^{61}$ Cf. PONTIFÍCIO INSTITUTO SUPERIOR DE DIREITO CANÔNICO DO RIO DE JANEIRO. Guia Acadêmico. Sem data. Rio de Janeiro, p. 10, disponível em http://pisdc.com.br/site/wpcontent/uploads/2010/10/Guia-Academico.pdf. e também como narrado resumidamente na citada página da internet.

${ }^{62} \mathrm{Cf}$. se constata em http://pisdc.com.br/site/institucional/organizacao/.
} 
Apostólica Sapientia Christiana e demais regulamentos, e delegado da PUG para ministrar o curso no Brasil. O diploma é expedido pela PUG.

O PISDC é por natureza jurídica instituição eclesiástica protegida pelo artigo $3^{\circ}$. do Acordo Brasil - Santa Sé e pelo já citado artigo 44 e $\S 1^{\circ}$. do Código Civil brasileiro. O parágrafo $1^{\circ}$. do citado artigo 44 do Código Civil brasileiro é categórico ao dispor ser livre a criação, a organização, a estruturação interna e o funcionamento das organizações religiosas, sendo vedado ao poder público negar-lhes reconhecimento ou registro necessário ao seu funcionamento.

Consequentemente, não há de se aplicar o artigo $2^{\circ}$. da Resolução CNE/CES n. 1 de 2001, pois o PISDC não é propriamente instituição de ensino brasileira associada a instituição de ensino estrangeira oferecendo curso de pós-graduação stricto sensu, mas instituição eclesiástica e romana agregada a $\mathrm{PUG}^{63}$. O PISDC em razão da sua ereção pontifícia e agregação à Faculdade de Direito Canônico da PUG recebe orientação, direção pedagógica, supervisão e fiscalização da PUG e da Congregação para a Educação Católica ${ }^{64}$.

$\mathrm{O}$ artigo $11^{\circ}$. da Lei de Introdução às Normas do Direito Brasileiro é claro ao dispor que "as organizações destinadas a fins de interesse coletivo, como as sociedades e as fundações, obedecem à lei do Estado em que se constituírem”. A PUG foi constituída na Santa Sé, assim como o PISDC uma vez que o ato de ereção é da Santa Sé, logo se regem pela legislação da Santa Sé ${ }^{65}$. O PISDC também se sujeita a lei brasileira para funcionamento no território nacional, conforme parágrafo $1^{\circ}$. do art. 11 da LINDB, ou seja, ao Acordo Brasil - Santa Sé, ao Código Civil e a Lei n. 9.396 de 1996.

O PISDC para funcionar regularmente no Brasil está sob administração da Mitra Arquidiocesana do Rio de Janeiro e não possui personalidade jurídica distinta da Mitra ${ }^{66}$. Assim, os seus atos constitutivos e ordinatórios são atos da Arquidiocese, da Santa Sé e da PUG regularmente expedidos segundo a legislação da Santa Sé e a legislação civil brasileira. Frise-se que a lei brasileira não cria restrição ou especial burocracia para o funcionamento das instituições eclesiásticas, pelo contrário. Como já explanado anteriormente, a mens legis do Acordo Brasil Santa Sé e dos dispositivos do Código Civil que tratam das organizações religiosas é a de facilitar

\footnotetext{
${ }^{63}$ Romano é a denominação dada aos que têm o equivalente a nacionalidade da Santa Sé. Deve também ser frisado que não é estranho ao direito brasileiro o reconhecimento de organizações com dupla nacionalidade, como, por exemplo, ocorre no Tratado para o Estabelecimento de um Estatuto das Empresas Binacionais Brasileiro-Argentinas citado por DEL'OLMO (2015, p. 221).

64 Cf. http://pisdc.com.br/site/quem-somos/ e http://pisdc.com.br/site/wp-content/uploads/2010/10/GuiaAcademico.pdf.

65 A doutrina é unânime ao interpretar literalmente o caput, v.g.: TENÓRIO (1976, v.2, p. 21-22) e RECHSTEINER(2015, p.184-195) esclarecendo que o Brasil se filia a teoria da incorporação.

66 Está registrado como estabelecimento filiado à Mitra Arquidiocesana do Rio de Janeiro, cf. http://www.empresascnpj.com/s/empresa/mitra-arquiepiscopal-do-rio-de-janeiro-nome-fantasia-institutosuperior-de-direito-canonico/33593575033470, apreendido em 17.3.2017.
} 
amplamente a criação, a organização, a estruturação interna e o funcionamento das organizações religiosas.

Por sua vez, quanto ao reconhecimento do diploma estrangeiro expedido por entidade vinculada a Santa Sé, o Acordo Brasil - Santa Sé remete às exigências da legislação nacional no artigo $9^{\circ}$. A legislação brasileira para reconhecimento de títulos acadêmicos é a Lei n. 9.394 de 1996, art. 48, parágrafo $3^{\circ}$., e a única exigência da lei é que os diplomas de mestrado e doutorado expedidos por instituições de ensino superior estrangeiras sejam reconhecidos por universidades brasileiras "que possuam cursos de pós-graduação reconhecidos e avaliados, na mesma área de conhecimento e em nível equivalente ou superior”. Consequentemente, resoluções, decretos ou regulamentos administrativos não podem restringir à aplicação da lei, pois hierarquicamente inferiores, e muito menos obstar o cumprimento de tratado internacional, e se o fazem sem qualquer justificativa técnica razoável não se aplicam às hipóteses em estudo nesse trabalho, ou são ilegais e não têm validade.

Outrossim, a nova Resolução CES/CNE n. 3 de 22 de junho de 2016, em seu artigo 32, revoga expressamente todas as disposições em contrário. A mens legis da nova Resolução é que o diploma estrangeiro de curso de pós-graduação stricto sensu que haja equivalência com o nacional seja reconhecido. Isso pode ser constatado facilmente pela mera leitura do Parecer CNE/CES n. 309/2015, que expõe os motivos para a nova resolução. Assim, a nova Resolução está plenamente sintonizada com o espírito do Acordo Brasil - Santa Sé e da Lei n. 9.394 de 1996.

Deve ser esclarecido ainda que, as restritivas Resoluções n CES/CNE n. 2 de 2001 e n. 2 de 2005 - que proibiram aos cursos de pós-graduação stricto sensu oferecidos diretamente no Brasil por instituições de ensino estrangeiras, ou oferecidos em convênio com instituições de ensino brasileiras, admitir novos alunos - não impedem o reconhecimento do diploma do mestrando da PUG que estudou integralmente no PISDC por três motivos: 1) não se coadunam com o disposto no Código Civil, com o disposto no tratado com a Santa Sé, nem com a Lei n. 9.394 de 1996; 2) criam situação de desigualdade material para os diplomados por meras razões temporais (diplomados antes e depois da promulgação dos acima citados regulamentos administrativos), em desrespeito a isonomia que deve haver no tratamento de todos os diplomados; 3) lesam direitos adquiridos.

Sobre o primeiro motivo muito já foi escrito e justificado anteriormente, mas não custa frisar: não pode mero regulamento restringir o disposto na lei. O parágrafo $1^{\circ}$. do artigo 44 do Código Civil ao dispor sobre as organizações religiosas é claríssimo ao afirmar ser livre o funcionamento das organizações religiosas, sendo vedado a administração pública "negar-lhes 
reconhecimento ou registro dos atos constitutivos e necessários ao seu funcionamento". A proibição de admissão de novos alunos significa negar funcionamento à organização religiosa.

Por sua vez, deve ser considerado que o acordo do Brasil com a Santa Sé, especialmente no seu artigo 10 e parágrafos $1^{\circ}$. e $2^{\circ}$., é peremptório ao dispor ser direito da Igreja Católica constituir e administrar instituições de ensino em todos os níveis e institutos eclesiásticos de formação e cultura, o que exige, obviamente, o direito de admitir alunos.

Outrossim, as alterações efetuadas posteriormente na Resolução CES/CNE n. 2 de 2001 não contribuem para a sua validade. A Resolução CES/CNE n. 2 de $2005 \mathrm{em}$ seu art. $1^{\circ}$. deu nova redação ao parágrafo $2^{\circ}$. do art. $1^{\circ}$. da Resolução CES/CNE n. 2/2001, e acrescentou como prazo prescricional um art. $3^{\circ}$. Criou assim uma situação que fere a isonomia constitucional assegurada a brasileiros e estrangeiros no Brasil pelo caput do art. $5^{\circ}$. da Constituição Federal, assim como viola direitos adquiridos, desrespeitando, portanto, também o inciso XXXVI do citado art. $5^{\circ}$ da Constituição Federal.

A Resolução CES/CNE n. 2 de 2005 determina prazos peremptórios e finais para o reconhecimento dos títulos acadêmicos, o que é flagrantemente abusivo, considerando que o título acadêmico e o grau a ele correspondente é um direito adquirido do diplomado ao qual a Lei n. 9.394 de 1996 não cria qualquer obstáculo temporal para o reconhecimento no Brasil.

Portanto, com relação a regularidade e a excelência dos cursos de pós-graduação stricto sensu em Direito Canônico e das instituições de ensino da Santa Sé, mesmo que o curso de mestrado ou doutorado tenha sido realizado totalmente em território nacional, não há de se fazer restrição ao reconhecimento do diploma que for expedido.

Por outro lado, quanto às formalidades exigidas nos incisos do parágrafo $4^{\circ}$. do art. 18 da Resolução n. 3, constata-se que visam apenas regulamentar o procedimento em nível nacional e que são razoáveis, que podem ser facilmente supridas pelos requerentes, e que contribuem para a segurança e qualidade do sistema de pós-graduação stricto sensu brasileiro, bastando, portanto, interpretá-las e observá-las literalmente.

Deve ser ressaltado que a cópia do diploma e demais documentos acostados ao requerimento de reconhecimento não podem estar meramente autenticados por notário brasileiro. Segundo o determinado na Resolução, o diploma deve trazer o registro expresso da instituição responsável pela diplomação, de acordo com a legislação vigente no Estado de origem, e estar autenticada por autoridade consular.

A exigência de autenticação consular é lícita. Trata-se de formalidade pela qual os agentes diplomáticos ou consulares do país em cujo território o documento deva surtir efeito e que exercem atribuições consulares no país onde o documento é produzido, certificam a 
autenticidade da firma e a qualidade do signatário do documento, ou seja, a identidade do selo ou timbre que o documento ostente (LOUREIRO, 2017, p. 1.225). Essa formalidade "confirma a autenticidade extrínseca do documento, ou seja, ratifica tão somente a identidade e a função da autoridade estrangeira signatária. A validade intrínseca do documento, referente ao seu conteúdo, deverá ser avaliada por autoridade brasileira competente" ${ }^{97}$. Essa formalidade prévia de legalização consular é essencial para que o documento estrangeiro produza efeitos jurídicos ${ }^{68}$.

A função notarial da repartição consular está amparada pela Convenção de Viena sobre Relações Consulares de $1963^{69}$, art. 50., "f”, regulamentada pelo Decreto n. 84.788 de 1980 e Decreto n. 8.742 de 2016, que revogou o Decreto n. 84.451 de 1980 o qual regulamentava anteriormente a matéria. Essa função consular é da maior importância, pois por estar a autoridade consular no país em que foi expedido o diploma, pode suprir quaisquer dúvidas que surgirem concernentes ao documento diretamente com a autoridade local que o expediu ou que reconheceu e autenticou a firma do agente expedidor (ARAUJO, 2012, p. 341-342).

Frise-se que o processo de legalização consular exige que o documento estrangeiro a ser submetido à legalização esteja antes autenticado por agente notarial do local de origem, inclusive a firma ou o sinal público, o que pode acarretar uma "corrente de certificações" antes da legalização consular (LOUREIRO, 2017, p. 468-469).

Embora a Resolução n. 3 ora em análise não exija, e o Decreto n. 8.742/2016 em seu art. $1^{\circ}$., e parágrafo $1^{\circ}$. pareça dispensar, segundo a Lei n. 6.015 de 1973 , art.129, $6^{\circ}$., os diplomas estrangeiros também deverão estar registrados no Registro de Títulos e Documentos. Isso porque o dispositivo legal citado é peremptório:

Art. 129. Estão sujeitos a registro, no Registro de Títulos e Documentos, para surtir efeitos em relação a terceiros: [...] $6^{\circ}$.) todos os documentos de procedência estrangeira, acompanhados das respectivas traduções, para produzirem efeitos em repartições da União, dos Estados, do Distrito Federal, dos Territórios e dos Municípios ou em qualquer instância, juízo ou tribunal;

${ }^{67}$ BRASIL. Ministério das Relações Exteriores. Portaria 457 de 2010, Manual do Serviço Consular e Jurídico, art. 4.7.2.

${ }^{68} \mathrm{Idem}$, art. 4.7.1. Nesse sentido a jurisprudência do Supremo Tribunal Federal (STF) e do Superior Tribunal de Justiça (STJ), v. g. no seguinte aresto do STF, SEC-4.738/EU. Rel. Min. Celso de Mello, DJ 07-04-95, p. 0871: "[...] O ato de chancela consular destina-se a conferir autenticidade ao documento formado no exterior (RTJ 49-148). Os cônsules brasileiros, quer em face de nosso ordenamento positivo interno, quer à luz do que prescreve a Convenção de Viena sobre relações consulares (1963), dispõem de funções certificantes e de autenticação de documentos produzidos por órgãos públicos do Estado estrangeiro perante o qual desempenham as suas atribuições. "

${ }^{69}$ Decreto n. 61.078 de 26 de julho de 1967. 
A legalização consular do diploma poderá ser substituída por apostilamento no futuro, caso a Santa Sé venha aderir a Convenção sobre a Eliminação da Exigência de Legalização de Documentos Públicos Estrangeiros da Conferência da Haia de Direito Internacional Privado ${ }^{70}$, ratificada pelo Brasil e promulgada pelo Decreto n. 8.660 de 29 de janeiro de 2016. Nesse caso, também ficaria dispensado o registro do diploma no Registro de Títulos e Documentos (LOUREIRO, 2017, p. 473-474, 1.231).

Também o exemplar da dissertação ou da tese apresentada e defendida junto à instituição de origem, com cópia em arquivo digital em formato compatível, deverá ser acostada ao procedimento de reconhecimento. Exemplar esse que deverá trazer registro de aprovação da banca examinadora e ser autenticado pela instituição de origem, e estar acompanhado da ata ou documento oficial da instituição de origem, contendo a data da defesa, o título do trabalho, a sua aprovação e conceitos outorgados. Todos os documentos devem estar devidamente autenticados por autoridade consular competente ou apostilados.

Quanto à tradução dos documentos acostados ao requerimento de reconhecimento, os parágrafos $5^{\circ}$. e $6^{\circ}$. do artigo da Resolução em comento dispõem que a instituição de ensino brasileira eleita para o reconhecimento do diploma estrangeiro só pode exigir se não estiverem redigidos em inglês, francês ou espanhol. Frise-se que, segundo a Resolução n. 3 em análise, não há obrigatoriedade de tradução para documentos e diplomas estrangeiros redigidos em outras línguas que não as francas citadas no parágrafo $6^{\circ}$. do art. 18. Logo, parece não haver óbice para que o diploma e os documentos redigidos em latim sejam aceitos pela universidade encarregada do reconhecimento do diploma de Mestre ou Doutor em Direito Canônico sem tradução para o português.

Por sua vez, a redação do parágrafo $6^{\circ}$. acima citado faz também crer que a tradução dos documentos e do teor do diploma estrangeiro, se for solicitada pela universidade requerida, poderá ser efetuada por qualquer tradutor, considerando que não há exigência de que seja efetuada por tradutor oficial, público ou dito juramentado.

No entanto, a liberalidade da Resolução no que tange a questão da tradução dos diplomas estrangeiros e demais documentos estrangeiros que devem acompanhar o processo de reconhecimento é questionável, e, a rigor, fere a lei.

70 Sobre a Convenção da Apostila da Haia, ver http://www.cnj.jus.br/poder-judiciario/relacoesinternacionais/convencao-da-apostila-da-haia. Frise-se que a Itália é parte da Convenção da Apostila, mas não a Santa Sé. Itália e Santa Sé firmaram acordo para reconhecimento comum de graus e diplomas de ensino superior, vez que ambas participam do Processo de Bologna, além de manterem disposições convencionais do Tratado de Latrão que se estendem em favor da PUG. 
Todo documento estrangeiro para produzir efeitos legais no Brasil deverá ser traduzido para o português, idioma oficial do país conforme art. 13 da Constituição Federal, em razão do determinado nos arts. 129, $6^{\circ}$. e 148 da Lei n. 6.015 de 1973 e art. 224 do Código Civil. O tradutor deverá ser necessariamente o Tradutor Público nomeado e registrado pela Junta Comercial, sob pena da tradução não ter fé pública nos termos do Decreto n. 13.609 de 1943, art. 19.

Destaque-se que o Supremo Tribunal Federal sempre foi peremptório ao exigir a tradução para o português dos documentos apresentados em processos de homologação de sentença estrangeira. Tradução essa realizada obrigatoriamente no Brasil por Tradutor Público e Juramentado, devidamente nomeado e inscrito na Junta Comercial ${ }^{71}$, dando, portanto, pleno cumprimento ao disposto no art. 15, letra "d", da Lei de Introdução às Normas do Direito Brasileiro, norma essa que foi repetida no Código de Processo Civil de 2015, art. 963, V.

Outrossim, o citado Código de Processo Civil é categórico ao dispor no art. 192, parágrafo único, que o "documento redigido em língua estrangeira somente poderá ser juntado aos autos quando acompanhado de versão para a língua portuguesa tramitada por via diplomática ou pela autoridade central, ou firmada por tradutor juramentado".

Portanto, é de bom alvitre traduzir o diploma expedido por instituição de ensino da Santa Sé para o português, valendo-se do serviço de Tradutor Público. Caso não haja Tradutor Público habilitado para o latim, deverá o interessado requerer a nomeação de tradutor ad hoc com base no parágrafo único do art. 19, do Decreto n. 13.609 de 1943, e art. 18, da Instrução Normativa DIREI n. 17 de 5 de dezembro de 2013, do Diretor do Departamento de Registro Empresarial e Integração.

Importante também mencionar o artigo 20 da Resolução CES/CNE n. 3, que assim dispõe:

Cursos de pós-graduação stricto sensu estrangeiros, cujos diplomas tenham sido objeto de reconhecimento nos últimos 10 (dez) anos, receberão, da universidade responsável pelo reconhecimento do diploma, tramitação simplificada.

A tramitação simplificada visa a agilizar e desburocratizar o processo de reconhecimento dos graus universitários estrangeiros, e poderá beneficiar o reconhecimento de diplomas de pós-graduação stricto sensu concedidos pelas instituições de ensino da Santa Sé.

As universidades deverão aguardar o lapso temporal determinado como mínimo na Resolução, dez anos contados a partir do primeiro reconhecimento, para adotar o procedimento simplificado. O procedimento simplificado não pode ser adotado considerando apenas ser

${ }^{71}$ Vide, por exemplo, SE-6.609, Rel. Min. Carlos Velloso. DJ 06/12/2000, j. 28/11/2000, p. 0009. 
instituição de ensino da Santa Sé genericamente, mas sim a origem institucional do diploma, logo, a própria universidade estrangeira.

A disposição é razoável, pois após dez anos reconhecendo diplomas de determinado curso de pós-graduação de determinada universidade, certamente todas as questões envolvendo as características do curso e que permitem o reconhecimento do diploma no Brasil já foram enfrentadas, não havendo porque maiores delongas na análise da documentação apresentada. $\mathrm{O}$ ideal, inclusive, é que a universidade na qual se dará o reconhecimento já tenha um protocolo para receber tais documentos, adequando os trâmites burocráticos da universidade às exigências formais do artigo 18 , parágrafo $4^{\circ}$. da Resolução em exame.

\section{Considerações Finais}

O presente trabalho demonstrou e provou ser o Direito Canônico uma disciplina eminentemente jurídica. Eventual interesse da Teologia pela disciplina não afeta a sua natureza, considerando que o seu objeto é o fenômeno jurídico. O Direito Canônico não é um discurso de fé religiosa ou sobre Deus, sua natureza, qualidades e relação com seus fiéis. Assim como não é um estudo sistemático sobre as práticas eclesiais e litúrgicas. Logo, não é Teologia ou ramo especializado da Teologia.

A Ciência Canônica tem por objeto o fenômeno jurídico no seio da Santa Sé e da Igreja Católica Apostólica Romana. Como Ciência Social aplicada, se materializa para os seus destinatários como sistema de normas coercitivo a estabelecer direitos e deveres. Nesse sentido, o Direito Canônico é essencialmente dogmático, jurídico e normativo, e visa disciplinar e organizar a vida e as práticas na Igreja de modo coercitivo para todos os seus membros. Assim, possui todos os elementos do saber jurídico e as principais características do Direito: a heteronomia, a coercibilidade e a bilateralidade atributiva. Por conseguinte, o Direito Canônico é epistemologicamente ramo da Ciência do Direito e está inserido nessa área de conhecimento.

Consequentemente, como as demais disciplinas jurídicas que têm por objeto o fenômeno jurídico e a normatividade, o método adequado de estudo, pesquisa e operação é o jurídico, utilizado pelo jurista.

A determinação do Direito Canônico como ramo do Direito repercute, também, na própria identidade científica dos profissionais dedicados a essa disciplina. Nesse último aspecto, significa que canonistas são juristas e que os graus, títulos e diplomas acadêmicos atribuídos a esses profissionais são pertinentes a área de conhecimento do Direito.

Portanto, considerando que esta pesquisa também provou serem às exigências romanas equivalentes às brasileiras para a obtenção de títulos, graus e diplomas de Pós-Graduação Stricto 
Sensu em Direito, não há motivo para não reconhecer esses diplomas em Direito Canônico expedidos por instituições de ensino superior da Santa Sé. Diplomas esses que podem e devem ser reconhecidos pelos Programas de Pós-Graduação em Direito brasileiros, mantidos por universidades públicas ou privadas, para que produzam plenamente todos os efeitos jurídicos correspondentes aos graus acadêmicos de Mestre ou Doutor em Direito atribuído ao titular do diploma.

Esse estudo demonstra ainda que as restrições impostas ao reconhecimento de diplomas expedidos por universidades estrangeiras, quando o curso é fornecido diretamente no Brasil, não se aplica aos diplomas expedidos pelas universidades eclesiásticas da Santa Sé.

Ademais, a análise realizada evidenciou que para o reconhecimento do diploma de Mestre ou Doutor em Direito Canônico expedido por instituição de ensino da Santa Sé, não basta a aplicação literal da Resolução CNE/CES n. 3 de 2016. A Resolução deve ser aplicada à luz da legislação específica aplicável a Santa Sé e as organizações religiosas: o Acordo Brasil - Santa Sé, promulgado pelo Decreto n. 7.107 de 2010, o Código Civil e a Lei n. 9.394 de 1996.

Outrossim, foi diagnosticado que a Resolução CNE/CES n. 3 de 2016 erra ou se omite em pontos fundamentais para a validade dos documentos acadêmicos no Brasil. A tradução da documentação acadêmica para o português é necessária, e a Lei de Registros Públicos deverá ser observada para a validade do reconhecimento do diploma expedido por qualquer universidade estrangeira, assim como as demais normas citadas sobre legalização consular, ou apostilamento se for o caso, a fim de que não venha a ser o ato de reconhecimento e equivalência do grau acadêmico estrangeiro eivado de vício com prejuízo para o detentor do diploma acadêmico estrangeiro e para a universidade reconhecedora ${ }^{72}$.

Por fim, após o decurso do lapso temporal determinado no artigo 20 da Resolução CES/CNE n. 3 de 2016, dez anos desde o primeiro reconhecimento de diploma de pós-graduação stricto sensu concedido por estabelecimento específico de ensino superior romano, deverá ser adotado o procedimento simplificado para reconhecimento de diploma pela universidade brasileira reconhecedora.

\footnotetext{
72 A palavra reconhecedora é adotada pela Resolução CNE/CES n. 3 de 2016 para identificar a universidade e os seus órgãos responsáveis pelo reconhecimento, trata-se, portanto, de nomen iuris as designações universidade reconhecedora, instituição reconhecedora ou órgão reconhecedor.
} 


\title{
ON THE RECOGNITION IN THE FEDERATIVE REPUBLIC OF BRAZIL OF POSTGRADUATE STRICTO SENSU DIPLOMA IN CANONIC LAW EXPEDED BY UNIVERSITY OF THE HOLY SEE
}

\begin{abstract}
This work investigates whether it is possible to recognize, in Brazil, a postgraduate diploma stricto sensu in Canon Law - issued by an institution of higher education belonging to the Holy See -, that produces effects equivalent to the academic degrees of Master or Doctor of Law conferred in the country. The Agreement between Brazil and the Holy See, in force since February 11, 2010, ensures the reciprocal recognition of diplomas and qualifications at the postgraduate level, in compliance with the requirements of the legal systems from Brazil and the Holy See. The issue is new and has not yet been addressed by the academy in its entirety despite its obvious importance. There is uncertainty about the legal nature of Canon Law, the requirements for granting the degree, and compatibility with the degree, Master or Doctor of Law conferred in Brazil. In order to achieve the desideratum of research, first the analytical method will be adopted with an examination of the doctrine, legislation and jurisprudence so that the nature of Canon Law can be determined, if it is a juridical or a theological knowledge; next, it will be verified if a higher education institution, maintained by the Holy See, can be considered a foreign institution of higher education and research according to Brazilian law; last, it will be verified if the diploma in Canon Law granted by the Roman university is apt for recognition, even if the stricto sensu postgraduate course is fully realized in Brazil.
\end{abstract}

KEYWORDS: Revalidation of foreign diploma; Recognition of degree, title or qualification in Canon Law; Brazil - Holy See Agreement; Catholic Church and Law; Law and Theology; Private International Law and Canon Law.

\section{Referências}

ACCIOLY, Hildebrando, SILVA, G.E. do Nascimento, e CASELLA, Paulo Borba. Manual de Direito Internacional Público. 17ª Ed. 2009. São Paulo: Saraiva.

AGUILLAR, Rafael Salomão Safe Romano. A Personalidade Jurídica da Igreja Católica no Brasil: do padroado ao Acordo Brasil - Santa Sé. 2015. S. Paulo: LTr.

ALEXY, Robert. Conceito e Validade do Direito. Organização: Ernesto Garzón Valdés et al. Tradução: Gercélia Batista de Oliveira Mendes. 2009. S. Paulo: WWF Martins Fontes.

ANDREAU-GUITRANCOURT, Pierre. Introduction Sommaire L'étude du Droit em Général et du Droit Canonique Contemporain en Particulier. 1963. Paris: Sirey.

ARAUJO, Nadia de. Direito Internacional Privado: teoria e prática brasileira. 2016. Porto Alegre: Revolução ebook. 
BALDISSERI, Lorenzo. Diplomacia Pontifícia: Acordo Brasil - Santa Sé, intervenções. 2011. S. Paulo: Ltr.

BALDISSERI, Lorenzo e MARTINS FILHO, Ives Gandra (coordenadores). Acordo Brasil Santa Sé Comentado. 2012. S. Paulo: LTr.

BERGEL, Jean-Louis. Teoria Geral do Direito. Tradução de Maria Ermantina de Almeida Prado Galvão. 2006. S. Paulo: Martins Fontes.

BITTAR, Eduardo C. B. e ALMEIDA, Guilherme de Assis. Curso de Filosofia do Direito. $8^{\mathrm{a}}$. Ed. 2010, S. Paulo: Atlas.

BOBBIO, Norberto. Teoria Geral do Direito. $2^{\mathrm{a}}$. Ed. 2008, S.Paulo: Martins Fontes.

BRASIL.CAPES, Diretoria de Avaliação. LIMA, Martonio Mont'Alverne Barreto, Coordenador de Área. Documento de Área 2013 - Área de Avaliação: Direito.

. Relatório de Avaliação Trienal 2013 da Coordenação de Aperfeiçoamento de Pessoal de Nível Superior - CAPES, do Ministério da Educação da República Federativa do $\begin{array}{llllll}\text { Brasil, } & \text { p. } & 25 & \text { e } & \text { s. } & \text { in }\end{array}$ https://docs.google.com/viewer?a=v\&pid=sites\&srcid=Y2FwZXMuZ292LmJyfHRyaWVuY WwtMjAxM3xneDo5NWRiMjB1OGY2ZDQ5ODA.

BRASIL. CONSELHO NACIONAL DE JUSTIÇA - CNJ. Sítio e documentos: $<$ http://www.cnj.jus.br/poder-judiciario/relacoes-internacionais/convencao-da-apostila-da-haia.

BRASIL. CONSELHO NACIONAL DE EDUCAÇÃO. CÂMARA DE EDUCAÇÃO SUPERIOR. Resolução n. 3, de 22 de junho de 2016. DOU p. 23/6/2016, n. 119, p.9-10. . Sítio e documentos:

Resolução CNE/CES n. 1 de 2001, Resolução CNE/CES n. 2 de 2001, Resolução CNE/CES n. 2 de 2005, Parecer CNE/CES 309/2015, in www.portal.mec.gov.br. 
BRASIL. Legislação utilizada e sítio consultado: Acordo Brasil - Santa Sé, Decreto n. 7.107 de 11 de fevereiro de 2010; Lei 9.394 de 1996; Constituição Federal; Convenção de Viena sobre Relações Consulares de 1963, Decreto n. 61.078 de 26 de julho de 1967; Decreto n. 84.788 de 1980; Decreto n. 8.742 de 2016; Decreto n. 84.451 de 1980; Lei n. 6.015 de 1973; Decreto n. 13.609 de 1943; Código Civil; Lei de Introdução às Normas do Direito Brasileiro - LINB; Código de Processo Civil - CPC; Instrução Normativa DIREI n. 17 de 5 de dezembro de 2013, do Diretor do Departamento de Registro Empresarial e Integração. In www.planalto.gov.br.

BRASIL. Ministério das Relações Exteriores. Portaria 457 de 2010, Manual do Serviço Consular e Jurídico.

BRASIL. SUPERIOR TRIBUNAL DE JUSTIÇA. SE - 6.516 - VA (2011/001820-4)(f). Rel. Ministro Presidente do STJ Félix Fischer, j. 16/05/2013; DJU 22/5/2013. http://www.stj.jus.br/SCON/decisoes/toc.jsp?processo=006516.NUM.\&\&tipo_visualizacao=R ESUMO\&b=DTXT\&thesaurus=JURIDICO\&p=true.

BRASIL. SUPREMO TRIBUNAL FEDERAL. SEC-4.738/EU. Rel. Min. Celso de Mello, DJ 07-04-95, p. 0871. . SE-6.609, Rel. Min. Carlos Velloso. DJ 06/12/2000, j. 28/11/2000, p. 0009.

COULANGES, Fustel de. A Cidade Antiga: estudos sobre o culto, o direito e as instituições da Grécia e de Roma, v.v. edições em francês, e em português com tradução de J. Cretella e Agnes Cretella, sem as notas de rodapé da edição original, pela RT.

COUNCIL OF EUROPE. Sítio e documentos: http:/www.coe.int/en/web/conventions/full-list/conventions/treaty/country/HOL?p_auth=XUmxKksJ.

DAVID, René. Os Grandes Sistemas de Direito Contemporâneo. Tradução de Hermínio A. Carvalho. 2002. S. Paulo: Martins Fontes.

DE LA BRIÈRE, Yves. "La Conditione Juridique de la Cité du Vatican”. Recuil de Cours, v. 33. 1930. Académie de Droit International de la Haye, p. 113-166. 
DEL'OLMO, Florisbal de Souza. Curso de Direito Internacional Privado. 2015. 11'a Ed. Rio: Forense.

DE PLÁCIDO E SILVA. Vocabulário Jurídico, vol. I e II. 4a. Ed. 1995. Rio: Forense.

DOLINGER, Jacob e TIBURCIO, Carmen. Direito Internacional Privado: parte geral e processo internacional.12a . ed. 2016. Rio: Forense.

EMPRESAS CNPJ.www.empresascnpj.com/s/empresa/mitra-arquiepiscopal-do-rio-de-janeironome-fantasia-instituto-superior-de-direito-canonico/33593575033470.

EUROPEAN HIGHEAR EDUCATION AREA AND BOLOGNA PROCESS. Sítio e documentos: $<$ http://www.ehea.info/pid34438/three-cycle-system.html.

$<$ http://www.ehea.info/.

FERRAZ Jr., Tercio Sampaio. Introdução ao Estudo do Direito: técnica, decisão, dominação. $6^{\mathrm{a}}$. Ed. 2008. S. Paulo: Atlas.

GASSIN, R. Systèm de droit”, Rev. Recherche juridique - droit prospectif, 1981, III.

GRAY, Nature and Source of Law, 51.

GIGANTE, José Antonio Martins. Instituições de Direito Canônico, v. I. $3^{\text {a }}$. Ed. 1955, Braga: S. José.

GONÇALVES, Mario Luiz Menezes. Introdução ao Direito Canônico. 2004. Petrópolis: Vozes.

HERVADA, Javier. O que é o Direito? A Moderna Resposta do Realismo Jurídico: uma introdução ao direito. Tradução de Sandra Martha Dolinsky. 2006. S. Paulo: WMF Martins Fontes.

. Lições Propedêuticas de Filosofia do Direito. Tradução de Elza Maria Gasparotto e Revisão Técnica de Gilberto Callado de Oliveira. 2008. WMF Martins Fontes: S. Paulo. 
HORTAL SJ, Jesús Pe., in SANTA SÉ. Código de Direito Canônico. Tradução: Conferência Nacional dos Bispos do Brasil - CNBB. 2008, 9ªd.e, S.Paulo: Ed. Loyola.

INSTITUTO DE DIREITO CANÔNICO SANTA CATARINA. http://isdcsc.org.br/institucional/, acesso em 17 de março de 2017.

JACQUES, Paulino. Curso de Introdução ao Estudo do Direito. 4ª Ed. 1981, Rio:Forense.

KELSEN, Hans. Teoria Geral do Direito e do Estado. Tradução Luís Carlos Borges. 2005. S. Paulo: Martins Fontes.

KLAUSNER, Eduardo A. Direito Internacional do Consumidor: a proteção do consumidor no livre-comércio internacional. 2012. Curitiba: Juruá.

KLAUSNER, Eduardo A. e ROSA, Pedro Paulo de Carvalho. "Sobre a natureza do Direito Canônico”. Lex Humana, Petrópolis, v. 10, n. 1, p. 40-62, 2018.

LE TOURNEAU, Dominique. O Direito na Igreja: iniciação ao Direito Canônico. Tradução de Luís Margarido Correia. 1998. Lisboa: Diel.

LIMA, Mons. Maurílio Cesar de. Introdução à História do Direito Canônico. 1999. São Paulo: Loyola.

LOSANO, Mário G. Os Grandes Sistemas Jurídicos. Tradução de Marcela Varejão. 2007. S. Paulo: Martins Fontes.

LOUREIRO, Luiz Guilherme.Registros Públicos: Teoria e Prática. 2017. 8a . ed. Salvador: Juspodivm.

MARQUES NETO, Agostinho Ramalho. A Ciência do Direito: conceito, objeto, método. $2^{\mathrm{a}}$. Ed. 2001.

MAZZUOLI, Valério de Oliveira. Curso de Direito Internacional Público. $7^{\mathrm{a}}$. Ed. 2012. S. Paulo: RT. 
MELLO, Celso D. de Albuquerque. Curso de Direito Internacional Público. V.1. 15ª . Ed. 2004. Rio: Renovar.

MORÊZ, Francielli. Introdução ao Direito Islâmico: evolução histórica, aspectos dogmáticos e elementos de inserção social. 2008. Curitiba: Juruá.

MÖRSDORF, K. Direito Canônico. FRIES, Heinrich (diretor). Dicionário de Teologia: conceitos fundamentais da teologia atual. Tradução do Pont. Col. Pio Brasileiro de Roma.1970. S.Paulo: Loyola.

PALMA, Rodrigo Freitas. Manual Elementar de Direito Hebraico. 2007, Curitiba: Juruá.

PONTIFÍCIA UNIVERSIDADE CATÓLICA DE GOIÁS. Reitor Prof. Wolmir Therezio Amado. Esclarecimentos do Reitor sobre o reconhecimento pontifício da Católica como PUC Goiás, 16 de setembro de 2009, in http://www.ucg.br/ucg/avisos/0249.asp, apreendido em 09 de fevereiro de 2017.

PONTIFICIA UNIVERSITÀ GREGORIANA. Sítios e documentos:

http://www.unigre.it/Univ/su/PUG_esenzione_it.php.

$<$ http://www.unigre.it/Studenti/processo_bologna_en.php $>$.

$<$ http://www.unigre.it/struttura_didattica/Diritto_canonico/brochure/090100_brochure_diritto_ canonico.pdf.

$<$ http://www.unigre.it/struttura_didattica/Diritto_canonico/specifico/brochure_diritto_canonico _en.php.

PONTIFÍCIO INSTITUTO SUPERIOR DE DIREITO CANÔNICO. Sítios e documentos:

$<$ http://pisdc.com.br/site/wp-content/uploads/2010/10/Guia-Academico.pdf 
$<$ http://pisdc.com.br/site/quem-somos/ content/uploads/2010/10/Guia-Academico.pdf.

REALE, Miguel. Lições Preliminares de Direito. 27ª Ed. 2007, S. Paulo: Saraiva.

REALE, Miguel.Filosofia do Direito. 20a. Ed., 2002, S. Paulo: Saraiva.

RECHSTEINER, Beat Walter. Direito Internacional Privado: teoria e prática. 17ª .ed. 2015. S. Paulo: Saraiva

RODAS, João Grandino. "Direito Canônico é aplicável no Brasil, por força de tratado ou de regras conflituais”. Consultor Jurídico.10/12/2015, 8h. Apreendida em <conjur.com.br>.

SAMPEL, Edson Luiz. "Direito e Igreja”. Revista de Cultura Teológica, v. 10, n. 40. Jul./Set. 2002, S.Paulo: PUC-SP. Versão eletrônica: $<$ http://revistas.pucsp.br/culturateo $>$.

SANTA SÉ. João Paulo II, PAPA. Constituição Apostólica “Sacrae Disciplinae Leges" de Promulgação do Código de Direito Canônico. 1983. Roma, Palácio Vaticano.

SANTA SÉ. João Paulo II, PAPA. Constituição Apostólica "Sapientia Christiana” Disponível em < http://w2.vatican.va/content/john-paul-ii/pt/apost_constitutions/documents/hf_jpii_apc_15041979_sapientia-christiana.html> apreendida em 10 de março de 2018.

SANTA SÉ. Comissão para a Revisão do Código de Direito Canônico. Prefácio. Código de Direito Canônico. 1983, Vaticano.

SANTA SÉ. Congregazione per l'Educazione Cattolica della Santa Sede em http://www.educatio.va/content/cec/it/studi-superiori-della-santa-sede.html, apreendido em 09 de fevereiro de 2017.

Cúria Romana.< http://www.vatican.va/roman_curia/congregations/ccatheduc/documents/rc_con_ccatheduc_20 051996_profile_en.html>. 
. Constituição Apostólica Pastor Bonus Sobre a Cúria Romana, disponível em http://paroquiasantoantoniopatos.com.br/admin/documentos/Constitui\%C3\%A7ao-ApostolicaPASTOR-BONUS-sobre-a-Curia-Romana.pdf.

SOARES, Ricardo Maurício Freire. Elementos de Teoria Geral do Direito. 2a ${ }^{\mathrm{a}}$ Ed. 2015, S.Paulo: Saraiva.

SÓBÁNSKI, Remigius. "Note sulla questione dela collazione sicentifica della canonistica". Communio, 1977.

STEFFEN. Carlos José Monteiro. Igreja e Direito Canônico: a dimensão jurídica do mistério da Igreja. Dissertação de Mestrado em Teologia. Pontifícia Universidade Católica do Rio Grande do Sul, 2014, Porto Alegre.

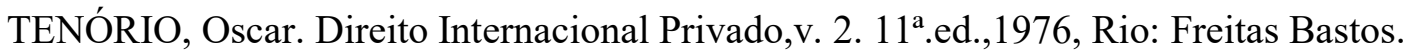

UNIVERSIDADE DE SÃO PAULO - USP. http://www.prpg.usp.br/index.php/pt-br/faca-posna-usp/programas-de-pos-graduacao/215-direito-fd $>$, apreendido em 30 de janeiro de 2017.

. Normas da Comissão Coordenadora do Programa

Direito, disponível in http://www.prpg.usp.br/uploads/norma-CCP-Direito-FD.pdf, apreendido em 30 de janeiro de 2017.

VARELLA, Marcelo D. e LIMA, Martonio Mont'alverne Barreto. "Políticas de revalidação de diplomas de pós-graduação em direito no Brasil: dificuldades e desafios para o sistema brasileiro". Revista Brasileira de Políticas Públicas, v. 2, n. 1, jan.-jun. 2012, Brasília, p. 145161, doi n. 10.5102/rbpp.v2i1.1814.

ZANI, Rubens Miraglia. “Os anjos e o Código de Direito Canônico”. Revista de Cultura Teológica, v. 15, n. 59. Abril/Jun. 2007, versão eletrônica.

Trabalho recebido em 01 de outubro de 2018

Aceito em 24 de fevereiro de 2019 